\title{
Historical Overview and Limnological Reconnaissance of Theodore \\ Roosevelt Lake, Arizona
}

By LISA K. HAM

U.S. GEOLOGICAL SURVEY

Water-Resources Investigations Report 95-4053

Prepared in cooperation with the ARIZONA DEPARTMENT OF

ENVIRONMENTAL QUALITY

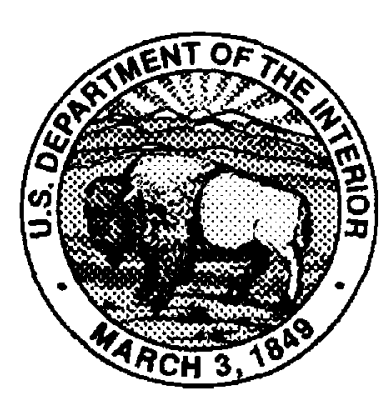




\title{
U.S. DEPARTMENT OF THE INTERIOR BRUCE BABBITT, Secretary
}

\author{
U.S. GEOLOGICAL SURVEY \\ Gordon P. Eaton, Director
}

Any use of trade, product, or firm names in this publication is for descriptive purposes only and does not constitute endorsement by the U.S. Government.

For additional information write to:

District Chief

U.S. Geological Survey Water Resources Division 375 South Euclid Avenue Tucson, AZ 85719-6644
Copies of this report can be purchased from:

U.S. Geological Survey

Open-File Section

Box 25286, MS 517

Denver Federal Center

Denver, CO 80225 


\section{CONTENTS}

Definition of terms

Abstract

Introduction

Purpose and scope

Acknowledgments

Physical setting.

Reservoir and stream characteristics.

Approach and methods.

Lake measurements and sample collection.

Inflow and outflow measurements and sample collection.

Laboratory analyses

Statistical methods

Historical overview

Salt River Project data..

U.S. Environmental Protection Agency studies

Arizona Department of Environmental Quality studies.

Arizona State University study..

Other studies.

Results of limnological reconnaissance, 1990-92.

Physicochemical stratification.

Water chemistry

Trophic status

Major ions

Dissolved metals

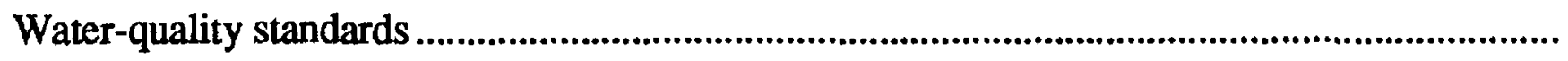

Bottom-sediment metals .

Summary and conclusions

\section{FIGURES}

1-2. Maps showing:

1. Location of study area, Theodore Roosevelt Lake, Arizona .

2. Pinal Creek basin, Arizona

\section{3-4. Graphs showing:}

3. Elevation of Theodore Roosevelt Lake and discharge from

Stewart Mountain Dam, Arizona, September 1990 through May 1992

4. Stream discharges for Salt River, Tonto Creek, and Pinal Creek, Arizona, September 1990 through May 1992

5. Map showing location of historical data-collection sites at

Theodore Roosevelt Lake, Arizona

6. Pie diagrams showing major constituent distribution in water from the Theodore Roosevelt Lake area, Arizona, 1980 through 1990 


\title{
CONTENTS
}

\author{
FIGURES-Continued
}

7. Map and graph showing data-collection sites and temperature profiles

from the limnological reconnaissance at Theodore Roosevelt Lake, Arizona

A. Map showing location of U.S. Geological Survey data-collection sites, 1990-92.

B. Graph showing temperature profiles for sites at the forebay, Salt bay, and Tonto arm, May 1992

8-11. Graphs showing:

8. Temperature, specific conductance, and dissolved-oxygen values in the forebay, Theodore Roosevelt Lake, Arizona, September 1990 through May 1992

9. Temperature, specific conductance, and dissolved-oxygen values in the Salt bay, Theodore Roosevelt Lake, Arizona, September 1990 through May 1992

10. Temperature, specific conductance, and dissolved-oxygen values in the Tonto arm, Theodore Roosevelt Lake, Arizona, September 1990 through May 1992

11. Relation of Secchi-disc depth to specific conductance and dissolved-oxygen concentration in the Tonto arm, Theodore Roosevelt Lake, Arizona, December 1991

12. Trilinear plots of compositions of water from Tonto Creek,

Salt River, and Theodore Roosevelt Lake, Arizona,

September 1990 through May 1992.

13. Diagram showing seasonal variations in the metalimnion in the

Salt bay, Theodore Roosevelt Lake, Arizona, September 1990

through May 1992.

TABLE

1. Morphometric features of Theodore Roosevelt Lake, Arizona

2. Statistical summary of nutrient data for Theodore Roosevelt Lake, Arizona, from the U.S. Environmental Protection Agency, 1975.

3. Total-nutrient loading of Theodore Roosevelt Lake, Arizona, 1975

4. Sediment-metal concentrations at Theodore Roosevelt Lake, Arizona, 1989

5. Statistical summary of nutrient data for Theodore Roosevelt Lake, Arizona, from the limnological reconnaissance, 1990-92

6. Statistical summary of selected dissolved-metal concentrations in water samples from the limnological reconnaissance of Theodore Roosevelt Lake, Arizona, 1990-92

7. Analyses from the limnological reconnaissance and Pinal Creek at Setka Ranch, Arizona, 1990-92, that exceeded or were outside the range of water-quality standards

8. Statistical summary of selected metal concentrations in bottomsediment samples from the limnological reconnaissance of Theodore Roosevelt Lake, Arizona, 1990-92. 


\section{CONTENTS}

\section{CONVERSION FACTORS}

\begin{tabular}{lcl}
\hline Multiply & By & To obtaln \\
\hline millimeter $(\mathrm{mm})$ & 0.03937 & inch \\
centimeter $(\mathrm{cm})$ & 0.3937 & inch \\
meter $(\mathrm{m})$ & 3.281 & foot \\
kilometer $(\mathrm{km})$ & 0.6214 & mile \\
hectare $(\mathrm{ha})$ & 2.471 & acre \\
liter $(\mathrm{L})$ & 0.2642 & gallon \\
cubic hectometer $\left(\mathrm{hm}^{3}\right)$ & 810.7 & acre foot \\
cubic meter per second $\left(\mathrm{m}^{3} / \mathrm{s}\right)$ & 35.31 & cubic foot per second \\
& 15,850 & gallon per minute \\
gram $(\mathrm{g})$ & 0.002205 & pound avoirdupois \\
microgram $(\mu \mathrm{g})$ & $2.205 \times 10^{-9}$ & pound avoirdupois \\
kilogram $(\mathrm{kg})$ & 2.205 & pound avoirdupois \\
\hline
\end{tabular}

In this report, temperature is reported in degrees Celsius $\left({ }^{\circ} \mathrm{C}\right)$, which can be converted to degrees Fahrenheit $\left({ }^{\circ} \mathrm{F}\right)$ by the following equation:

$$
{ }^{\circ} \mathrm{F}=1.8\left({ }^{\circ} \mathrm{C}\right)+32
$$

\section{ABBREVIATED WATER-QUALITY UNITS}

Chemical concentration and water temperature are given only in metric units. Chemical concentration in water is given in milligrams per liter $(\mathrm{mg} / \mathrm{L})$ or micrograms per liter $(\mu \mathrm{g} / \mathrm{L})$. Milligrams per liter is a unit expressing the solute mass per unit volume (liter) of water. One thousand micrograms per liter is equivalent to 1 milligram per liter. For concentrations less than 7,000 milligrams per liter, the numerical value is about the same as for concentrations in parts per million (ppm). Specific conductance is given in microsiemens per centimeter $(\mu \mathrm{S} / \mathrm{cm})$ at $25^{\circ} \mathrm{C}$. Chemical concentration in sediment samples is given in micrograms per gram $(\mu \mathrm{g} / \mathrm{g})$. Micrograms per gram is equivalent to parts per million.

\section{VERTICAL DATUM}

Sea level: In this report, "sea level" refers to the National Geodetic Vertical Datum of 1929-A geodetic datum derived from a general adjustment of the first-order level nets of the United States and Canada, formerly called "Sea Level Datum of 1929." 


\section{DEFINITION OF TERMS}

Definition of terms is derived from Bates and Jackson (1980) and Chow (1964).

Chemocline-The zone where salinity or specific conductance increases rapidly with depth.

Development of shoreline-The ratio of shoreline length to the circumference of a circle whose area equals the surface area of the lake.

Development of volume (dv) - A comparison of the volume of the lake with that of a cone; a circular lake would have $a d v=1, a d v>1$ represents a lake with basin walls that are concave toward the water.

Dissolved-oxygen minima-A severe reduction in oxygen that can be caused by various processes.

Epilimnion-The uppermost layer of water in a lake, characterized by an essentially uniform temperature that generally is warmer than elsewhere in the lake and by a relatively uniform mixing caused by wind and wave action.

Eutrophic lake-A lake characterized by an abundance of dissolved plant nutrients and by a seasonal deficiency of oxygen in the hypolimnion; its deposits usually have considerable amounts of rapidly decaying organic mud and its water is frequently shallow.

Forebay-The area of the reservoir that is immediately uplake from the dam face.

Hydraulic retention-The storage time of a reservoir is determined by dividing the reservoir volume by mean flow of outlet.

Hypolimnion-The lowermost layer of water in a lake, characterized by an essentially uniform temperature (except during a turnover) that generally is colder than elsewhere in the lake, and often is characterized by relatively stagnant or oxygen-poor water.

Limnology-The scientific study of the physical, chemical, meteorological, biological, and ecological conditions and characteristics of lakes.

Maximum depth-The greatest depth sounded in the lake.

Maximum length - A line along the water's surface that represents the true open-water length of the lake, this line does not have to be straight and may cross islands.

Maximum width-The straight-line distance between the most separated shores, which is approximately perpendicular to the maximum length.

Mean depth-A calculated value of volume divided by area.

Mean width - A calculated value of surface area divided by maximum length.

Mesotrophic lake-A lake that is characterized by a moderate supply of nutrient matter, neither notably high nor low in its total production; it is intermediate between a eutrophic lake and an oligotrophic lake.

Metalimnion-The horizontal layer of a thermally stratified lake in which the temperature decreases rapidly with depth. The metalimnion lies between the epilimnion and the hypolimnion and includes the thermocline.

Monomictic (lake) —A lake with only one yearly tumover.

Morphometry-The measurement of the form characteristics (area, depth, length, width, volume, and bottom gradients) of lakes and their basins.

Oligotrophic lake-A lake that is characterized by a deficiency in plant nutrients and usually by abundant dissolved oxygen in the hypolimnion; its bottom deposits have relatively small amounts of organic matter and its water is often deep. 
Pan evaporation coefficient-Provides an estimate of annual evaporation losses from reservoirs.

Penstocks-Dam structures that conduct water from the reservoir through the dam to the turbines in the powerplant.

Physicochemical—Relating to properties that are both physical and chemical.

Senescence-A lake that is approaching extinction as a result of sediment filling, erosion of the outlet, or other causes.

Slope of basin-The slope of the basin is expressed as a percent of 45 degrees.

Shoreline length-The length of the shoreline circumference.

Surface area-The area enclosed within the zero-depth contour on a bathymetric map.

Turnover-A period (usually in the fall or spring) of uniform vertical temperature when convective circulation occurs in a lake.

Volume-Area enclosed by the depth contours plotted against depth, and the area under the curve so obtained may be planimetered or otherwise measured. 


\title{
Historical Overview and Limnological Reconnaissance of Theodore Roosevelt Lake, Arizona
}

\author{
By Lisa K. Ham
}

\section{Abstract}

Theodore Roosevelt Lake (Roosevelt Lake) is a reservoir on the Salt River and Tonto Creek and a public water supply for the Phoenix, Arizona, metropolitan area. Roosevelt Lake potentially could be affected by contamination from the Pinal Creek basin and other upstream areas. Ground water in parts of the Pinal Creek basin contains elevated concentrations of manganese, copper, and other metals and contributes to the flow of Pinal Creek, which is a tributary of the Salt River. The purpose of this study was to determine the basic limnological processes within Roosevelt Lake using historical data and data collected by the U.S. Geological Survey during 1990-92.

Major-ion concentrations indicate that Roosevelt Lake is chemically influenced more by the Salt River than by Tonto Creek. Calcium and bicarbonate are predominant in water from Tonto Creek; sodium and chloride are predominant in water from the Salt River and Roosevelt Lake. A semilog-regression analysis of discharge from the Salt River resulted in a coefficient of determination $\left(\mathrm{r}^{2}\right)$ of 0.79 for chloride and 0.73 for sodium. The greatest coefficient of determination for a constituent with discharge from Tonto Creek was bicarbonate $(0.18)$. On the basis of stream inputs, discharge is not a good predictor of water chemistry leaving the dam.

Roosevelt Lake is a warm, monomictic reservoir. Data collected during this study indicate that Roosevelt Lake begins thermal stratification in February and becomes strongly stratified by April. Temperature and specific-conductance data indicate that thermal turnover was completed by December, although the dissolved-oxygen data were more indicative of a stratified condition.

Overall, Roosevelt Lake is considered to be mesotrophic. However, chlorophyll- $a$ concentrations ranged from 0.70 to 14 micrograms per liter, and the mean concentration was 2.8 micrograms per liter, indicating oligotrophy. The Secchi-disc depth ranged from 1.1 to 3.0 meters, and the mean depth was 1.9 meters, indicating eutrophy.

Mean concentrations of dissolved arsenic, iron, manganese, nickel, and strontium were less in Roosevelt Lake than in the Salt River and Tonto Creek. The median concentration of dissolved manganese was 0.45 micrograms per liter for the lake sites and 22 micrograms per liter for the stream sites. Concentrations of dissolved copper and zinc were greater in the lake than in the streams. The mean concentration of dissolved copper was 3.1 micrograms per liter for the lake sites and 1.6 micrograms per liter for the stream sites.

Of the lake sites, the forebay had the greatest mean concentrations of dissolved arsenic, iron, manganese, and zinc. The mean concentration of dissolved manganese for the forebay (114 micrograms per liter) was more than two times that for the Salt bay ( 46 micrograms per liter). This increase in concentration may be due to the greater thickness of the hypolimnion at the forebay, resulting in a larger reducing zone where metals desorb from sediments.

The mean concentrations of chromium, copper, and zinc in the bottom sediment were greater for stream sites than for lake sites. The mean concentrations of metals were greater for the bottom sediment from the Salt River than for those from Tonto Creek.

In the lake, mean concentrations of chromium, copper, nickel, and zinc in bottom sediment were greatest for sediment from the Tonto arm. Barium concentrations were greatest in bottom sediment from the Salt bay. 


\section{INTRODUCTION}

A system of reservoirs on the Salt and Verde Rivers provides most of the water used for irrigation in the Salt River Project (SRP) delivery area and for public water supply in the Phoenix, Arizona, metropolitan area. Two reservoirs on the Verde River and four on the Salt River provide a total storage capacity of about $2,490 \mathrm{hm}^{3}$ (Boner and others, 1992). About 66 percent of the storage in the Salt River system is provided by Theodore Roosevelt Lake (Roosevelt Lake) (Boner and others, 1992). Roosevelt Lake is an impounded river that was created with the construction of Theodore Roosevelt Dam (Roosevelt Dam) from 1904-11 and was the first in a series of reservoirs to be created on the Salt River for flood control (fig. 1). The reservoirs also are used for power generation, storage of irrigation water, and recently, have been used for recreational activities.

Ground water in parts of the Pinal Creek basin (fig. 2) contains elevated concentrations of dissolved solids and metals and contributes flow to Pinal Creek, a tributary of the Salt River. Dissolved-solids concentrations in Pinal Creek increased from about $2,700 \mathrm{mg} / \mathrm{L}$ in 1980 to about $3,500 \mathrm{mg} / \mathrm{L}$ in 1989 (Eychaner, 1991). The concentrations of dissolved sulfate and manganese also increased during the same period. Concentrations of dissolved nickel began to increase in 1988, concentrations of dissolved iron began to increase in 1989, and alkalinity (buffering capacity) began to decrease in 1989 . The plume of contaminated ground water was estimated to be moving downgradient at a rate of 0.2 to $0.3 \mathrm{~km} / \mathrm{yr}$ (Eychaner, 1991).

The water quality of Roosevelt Lake potentially could be affected by contamination from the Pinal Creek basin and other areas. Current conditions in the lake need to be determined so that any changes in the water quality of Roosevelt Lake that might occur as a result of contamination can be assessed. A study of current conditions was done by the U.S. Geological Survey (USGS) in cooperation with the Arizona Department of Environmental Quality (ADEQ). The objectives of this study were to develop a data-collection program; estimate hydrologic, sediment, and chemical budgets for the lake from historical data; evaluate the spatial and temporal distribution of physical and chemical conditions through a limnological survey of the lake; and evaluate, on a reconnaissance level, the extent and concentration of metals in the upper layers of bottom sediments. In this report, the term "metals" is used to denote metals and metalloids. This study fulfills part of the Clean Lakes Program Phase I Diagnostic and Feasibility study elements required by the U.S. Environmental Protection Agency (USEPA).

\section{Purpose and Scope}

This report reviews the physical and chemical limnology of Roosevelt Lake obtained from previous studies and presents baseline data collected during the USGS study. Water samples were collected by the USGS six times during the study (September 1990; April, August, and December 1991; and March and May 1992) and analyzed for major ions, total nutrients, and dissolved metals. The sampling included three lake sites (Salt bay, Tonto arm, and forebay), two inflow sites (Salt River and Tonto Creek), and the outflow from Roosevelt Dam. At each of the three lake sites, three water samples were collected at depths that were selected on the basis of thermal stratification except for the high-flow sampling done in March 1992 when water samples were collected only from the metalimnion.

Bottom-sediment samples were collected and analyzed for metals four times during the study (April, August, and December 1991, and May 1992). The sampling included the Salt bay, Tonto arm, and forebay; two sites on the Salt arm (at $\mathrm{km} 16$ and $\mathrm{km} 9.5$ from the dam); and the two inflow sites (Salt River and Tonto Creek). Bottom-sediment samples were collected from the lake sites in April 1991 using a BM-54 bottom-sediment sampler and in August and December 1991 and May 1992 using a core bottom-sediment sampler.

\section{Acknowledgments}

Patricia Spindler and Thomas Trent of the ADEQ assisted with the collection of lake samples. 


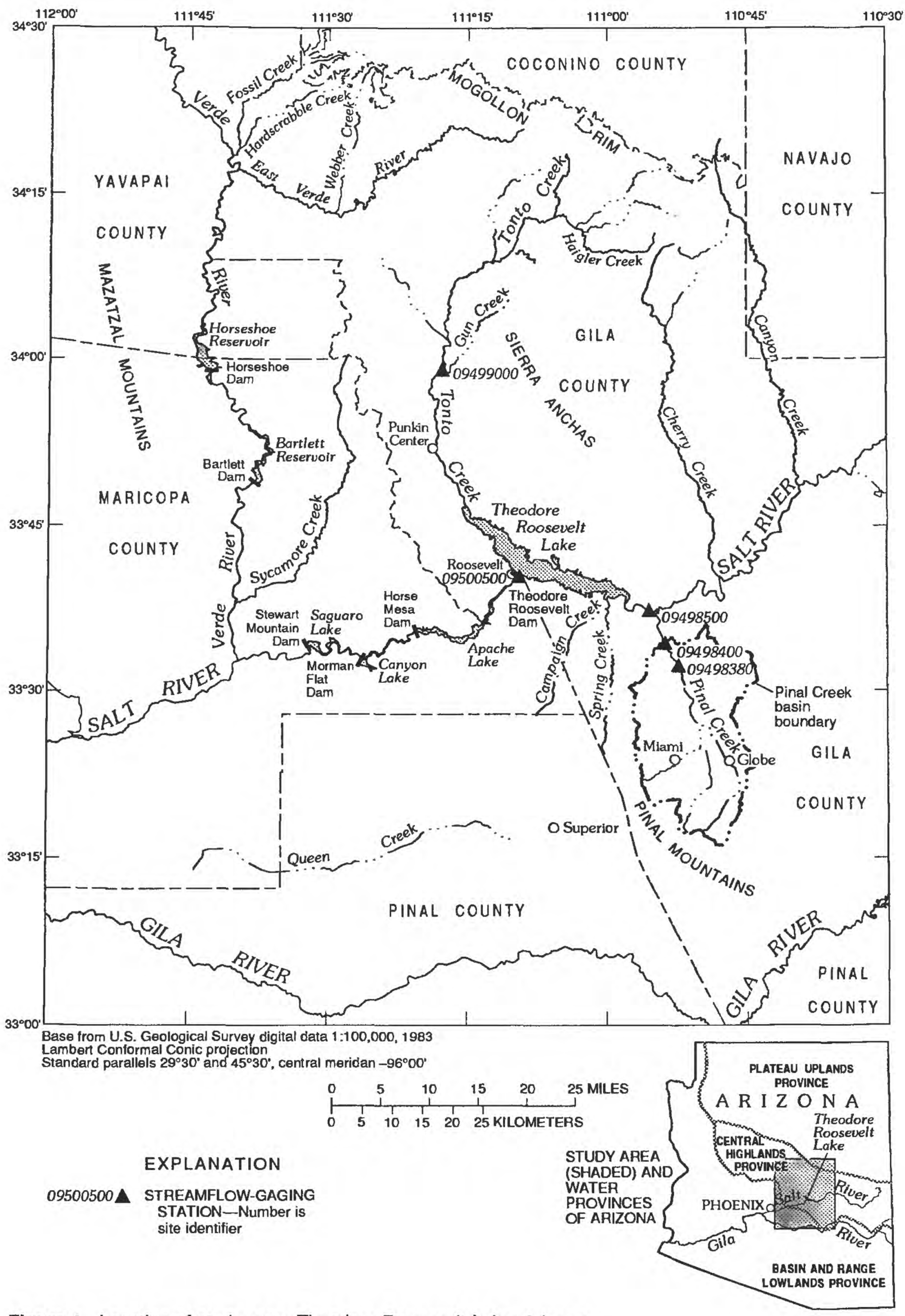

Figure 1. Location of study area, Theodore Roosevelt Lake, Arizona. 


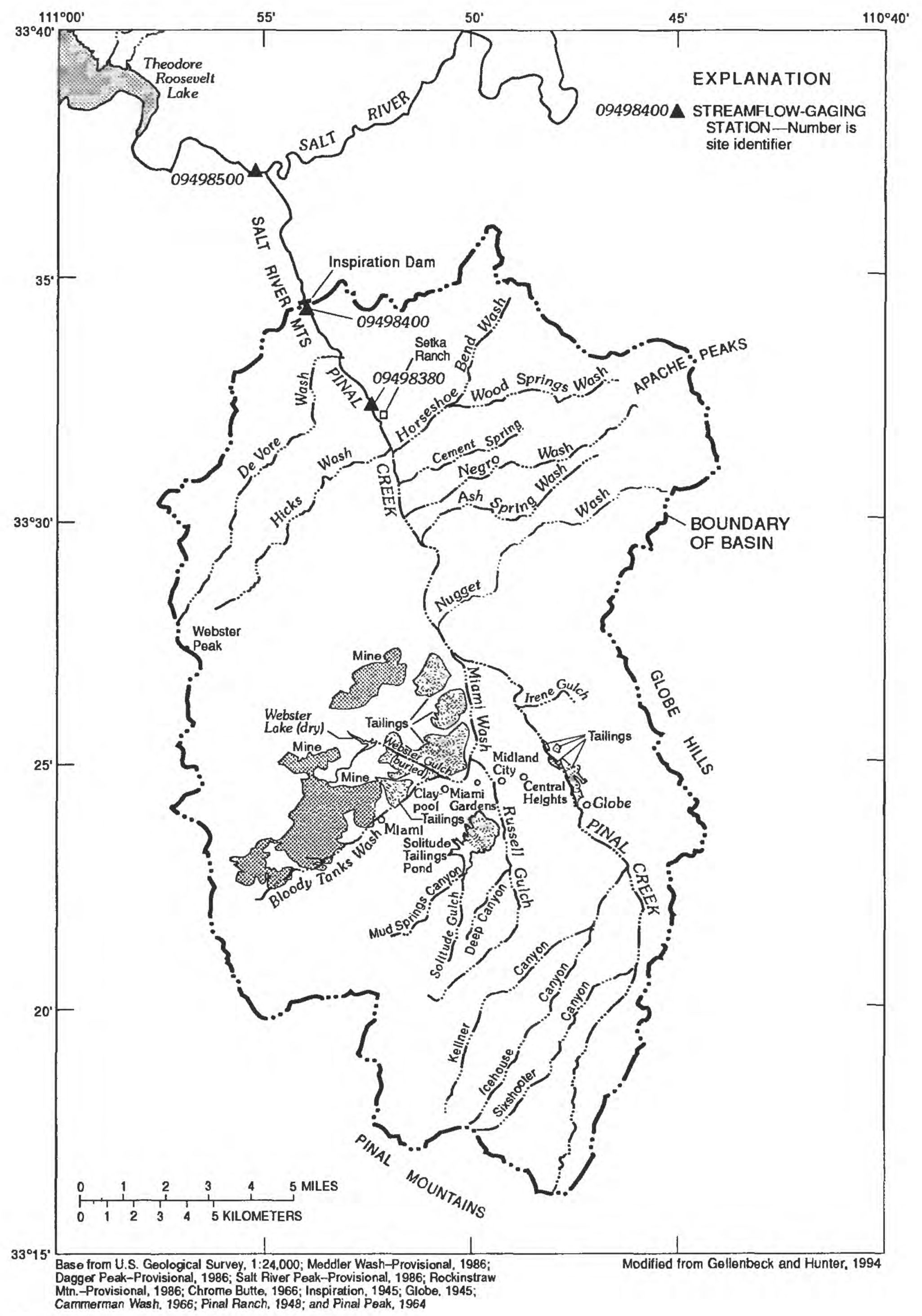

Figure 2. Pinal Creek basin, Arizona. 
The Arizona Department of Health Services (ADHS) provided analyses of 63 water samples and 27 bottom-sediment samples. The Bureau of Reclamation (BOR) provided access to the outflow from Roosevelt Dam during the limnological reconnaissance.

\section{Physical Setting}

Roosevelt Lake is in the Central highlands water province (fig. 1). This province is a transitional zone between the Plateau uplands province to the northeast and the Basin and Range province to the southwest. The Central highlands province is characterized by isolated mountain ranges cut by steep-walled canyons and many ephemeral streams (Sellers and Hill, 1974).

Roosevelt Lake is in an area characterized by hot, dry summers and mild winters. Average air temperatures from June to September are above $29^{\circ} \mathrm{C}$ (Sellers and Hill, 1974). Daily air temperatures range from $24^{\circ}$ to $40^{\circ} \mathrm{C}$ during the warmest months of July and August; winter temperatures peak in the afternoon to about $15^{\circ} \mathrm{C}$ (Seller and Hill, 1974). In the Central highlands province, 46 percent of the annual precipitation occurs from December to March (Sellers and Hill, 1974) and approximately 30 percent occurs from July to September (Green and Sellers, 1964).

\section{Reservoir and Stream Characteristics}

Roosevelt Lake is a bilaterally shaped reservoir at the confluence of the Salt River and Tonto Creek. The lake receives water from the Salt River, Tonto Creek, and many small washes along its shores. The average inflow from the Salt River and Tonto Creek was $30 \mathrm{~m}^{3} / \mathrm{s}$ for 1942-91 (Boner and others, 1992).

During this study, Roosevelt Dam was being modified by construction, and the BOR was required to maintain a lake elevation of approximately 645 m (Dallas Regal, Salt River Project, oral commun., 1991). Because the actual discharge values from Roosevelt Dam were difficult to obtain, the lake levels were determined from releases from Stewart Mountain Dam (Dallas Regal, Salt River Project, oral commun(s)., 1992). Discharges from Roosevelt Dam generally are inversely correlated with lake elevation (fig. 3 ). The highest lake elevation during sampling was in April

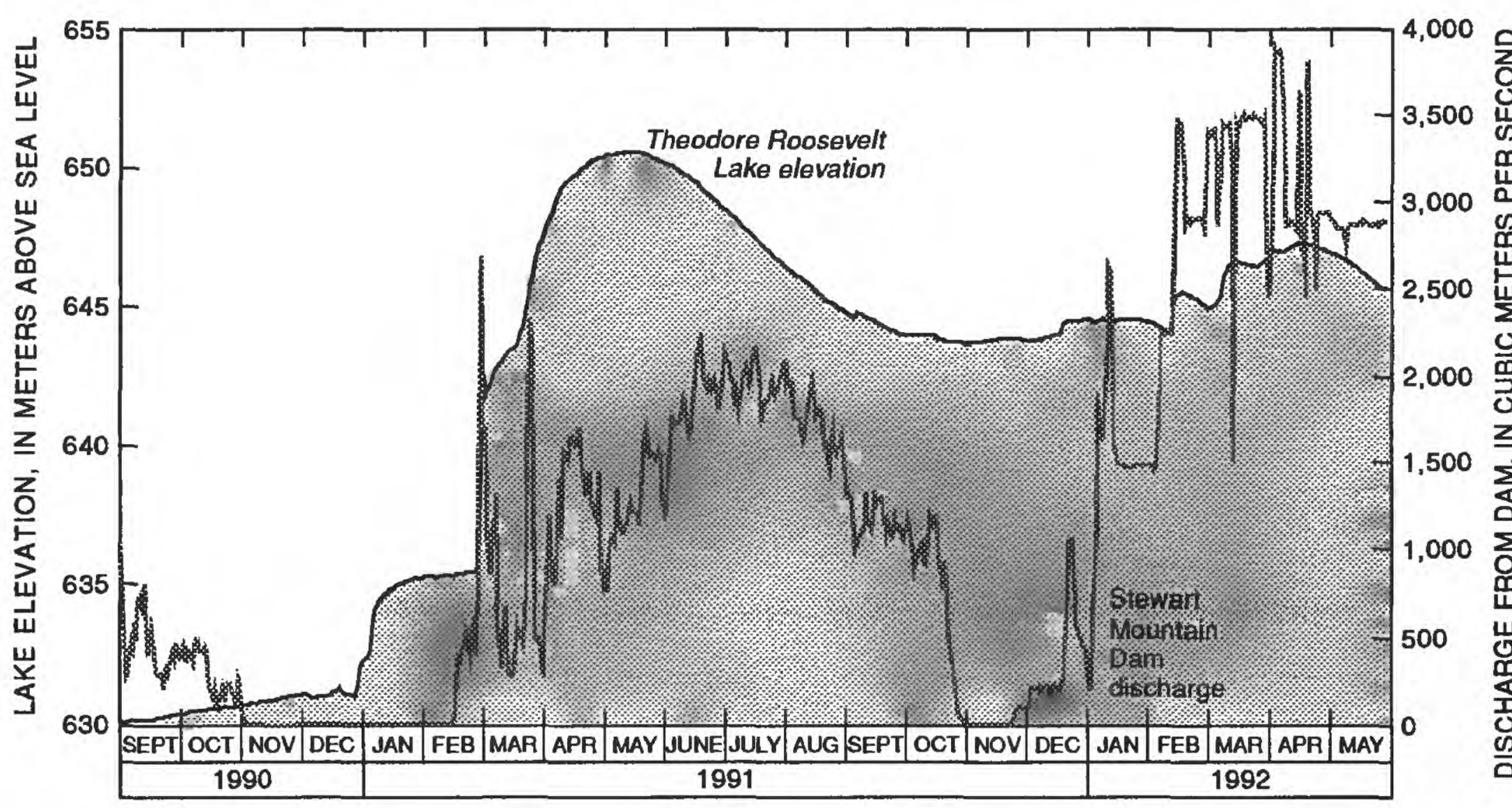

Flgure 3. Elevation of Theodore Roosevelt Lake and discharge from Stewart Mountain Dam, Arizona, September 1990 through May 1992. 
1991; the lowest elevation was in September 1990. The maximum discharge from Stewart Mountain Dam during sampling occurred in March 1992, the next greatest occurred in May 1992. Mean storage for the study period was $1,106 \mathrm{hm}^{3}$ (Salt River Project, unpublished data, 1992). The mean storage increased significantly from $716 \mathrm{hm}^{3}$ in February 1991 to $1,523 \mathrm{hm}^{3}$ in April 1991. After this increase, the daily storage remained more than $1,110 \mathrm{hm}^{3}$ for the rest of the study.

Historical data from Roosevelt Lake differ slightly for values of certain morphometric features, depending on the source and date of the data (table 1). According to Lara (1982), the Salt arm of the lake is $25.4 \mathrm{~km}$ long and averages $1.9 \mathrm{~km}$ wide and the Tonto arm is $17.5 \mathrm{~km}$ long and averages $1.4 \mathrm{~km}$ wide. The estimated total storage capacity is $1,704 \mathrm{hm}^{3}$, the maximum depth is $62.5 \mathrm{~m}$, and the surface area is about 7,010 ha (Rinne, 1973). A bathymetric survey of Roosevelt Lake done in 1909 indicated a surface area of $7,214 \mathrm{ha}$, total storage capacity of $1,877 \mathrm{hm}^{3}$, and an elevation (at the top of the spillway gates) of $651 \mathrm{~m}$ (Lara, 1982). In 1981, the 1909 data were used to recalculate the total storage capacity, resulting in a value of $1,887 \mathrm{hm}^{3}$ (Lara, 1982). A replacement dam scheduled for completion in 1994 will increase the storage capacity of the lake to $1,985 \mathrm{hm}^{3}$, raise the lake level to a maximum depth of $84.5 \mathrm{~m}$, and increase the maximum surface area to 7,770 ha (Joel Sturm, Bureau of Reclamation, oral commun., 1993). The average evaporation rate for 1963-73 was $249 \mathrm{~cm} / \mathrm{yr}$ (Sellers and Hill, 1974). Pan coefficients provide an estimate of annual evaporation losses from reservoirs based on the measured evaporation from pans. According to Green and Sellers (1964), the annual pan coefficient for Roosevelt Lake for 1915-61 was 0.69.

Pinal Creek originates in the Pinal Mountains, south of Globe, Arizona, and flows into the Salt River approximately $0.5 \mathrm{~km}$ upstream from the Salt River sampling site. The total drainage area for the Pinal Creek basin above streamflow-gaging station, Pinal Creek at Inspiration Dam near Globe (09498400), is 50,500 ha, of which about 8,500 ha is partly or entirely noncontributing owing to mining operations in the Globe area (Boner and others, 1992). The general water type for Pinal Creek is calcium and sulfate with magnesium as a
Table 1. Morphometric features of Theodore Roosevelt Lake, Arizona

[m, meters; $\mathbf{k m}$, kilometers; ha, hectare; $\mathrm{hm}^{3}$, cubic hectometers; $y r_{\text {, }}$ years; --, not calculated. See definition of terms]

\begin{tabular}{|c|c|c|}
\hline Morphometric feature & Rinne (1973) & $\begin{array}{l}\text { U.S. Environ- } \\
\text { mental Protection } \\
\text { Agenoy (1977) }\end{array}$ \\
\hline Maximum depth ............... & $62.5 \mathrm{~m}$ & $71.3 \mathrm{~m}$ \\
\hline 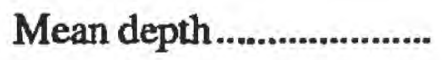 & $24.3 \mathrm{~m}$ & $28.0 \mathrm{~m}$ \\
\hline Maximum breadth ........... & $3.87 \mathrm{~km}$ & - \\
\hline Mean breadth ................... & $2.08 \mathrm{~km}$ & - \\
\hline Length............................. & $33.7 \mathrm{~km}$ & - \\
\hline Shoreline length.............. & $158.8 \mathrm{~km}$ & (2)-- \\
\hline Surface area ...................... & $7,010 \mathrm{ha}$ & $6,070 \mathrm{ha}$ \\
\hline Volume.............................. & $1,704 \mathrm{hm}^{3}$ & $1,704 \mathrm{hm}^{3}$ \\
\hline 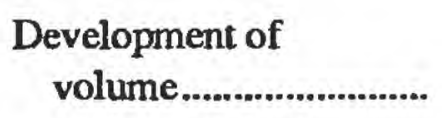 & 1.17 & - \\
\hline $\begin{array}{l}\text { Development of } \\
\text { shoreline ......................... }\end{array}$ & 5.34 & -1.n-n \\
\hline Slope of basin ................... & 7.0 & - \\
\hline $\begin{array}{l}\text { Mean hydraulic reten- } \\
\text { tion time........................ }\end{array}$ & - & 694 days $(1.9 \mathrm{yr})$ \\
\hline
\end{tabular}

principal component. The mean specific conductance was $3,412 \mu \mathrm{S} / \mathrm{cm}$, and the mean dissolved-solids concentration was $3,223 \mathrm{mg} / \mathrm{L}$ for November 1990 to October 1991. The average discharge for 1981-91 was $0.31 \mathrm{~m}^{3} / \mathrm{s}$ and the maximum discharge was $82.7 \mathrm{~m}^{3} / \mathrm{s}$ in July 1981 ; base discharge in 1990 was $5.7 \mathrm{~m}^{3} / \mathrm{s}$ (Boner and others, 1992).

The Salt River is the major tributary of Roosevelt Lake. The total drainage area above streamflow-gaging station, Salt River near Roosevelt (09498500), located 27 km upstream from Roosevelt Dam on the Salt River, is 1,115,300 ha (Boner and others, 1992). Upstream from the station, the basin is sparsely populated; land use includes livestock grazing, mining, and timber harvesting. The Salt River contains high concentrations of sodium and chloride ions and significant amounts of calcium and bicarbonate ions. A principal source of dissolved salts in the 
river has been traced to saline springs above Roosevelt Lake, providing the Salt River with its name (Arizona Department of Environmental Quality, 1992a). The mean specific conductance for 1976-89 was $2,000 \mu \mathrm{S} / \mathrm{cm}$, and the mean dissolved-solids concentration was $1,120 \mathrm{mg} / \mathrm{L}$. The average discharge for this site for 1913-91 was $25 \mathrm{~m}^{3} / \mathrm{s}$ (Boner and others, 1992). The maximum discharge for 1913-91 was $3,314 \mathrm{~m}^{3} / \mathrm{s}$ in March 1941; the minimum discharge was $1.7 \mathrm{~m}^{3} / \mathrm{s}$ in July 1955 (Boner and others, 1992). Base discharge in 1990 was $113 \mathrm{~m}^{3} / \mathrm{s}$ (Boner and others, 1992). During this study, the greatest inflow from the Salt River during sampling was in April 1991 and March 1992 (fig. 4).

Tonto Creek originates near the Mogollon Rim and flows southward into Roosevelt Lake. The total drainage area for the Tonto Creek basin above the streamflow-gaging station, Tonto Creek above Gun Creek near Roosevelt (09499000), is 174,800 ha (Boner and others, 1992). The part of Tonto Creek basin above the gaging station is sparsely populated; land use includes livestock grazing, timber harvesting, mining, and recreation. Increased turbidity and concentrations of phosphorus and ammonia are thought to be the result of sand and gravel operations and range-land practices along Tonto Creek (Arizona Department of Environmental Quality, 1992a). The general water type for Tonto Creek is calcium and bicarbonate. Based on periodic measurements made between January 1976 and August 1991, the mean specific conductance was $419 \mu \mathrm{S} / \mathrm{cm}$ and the mean dissolved-solids concentration was $234 \mathrm{mg} / \mathrm{L}$. The

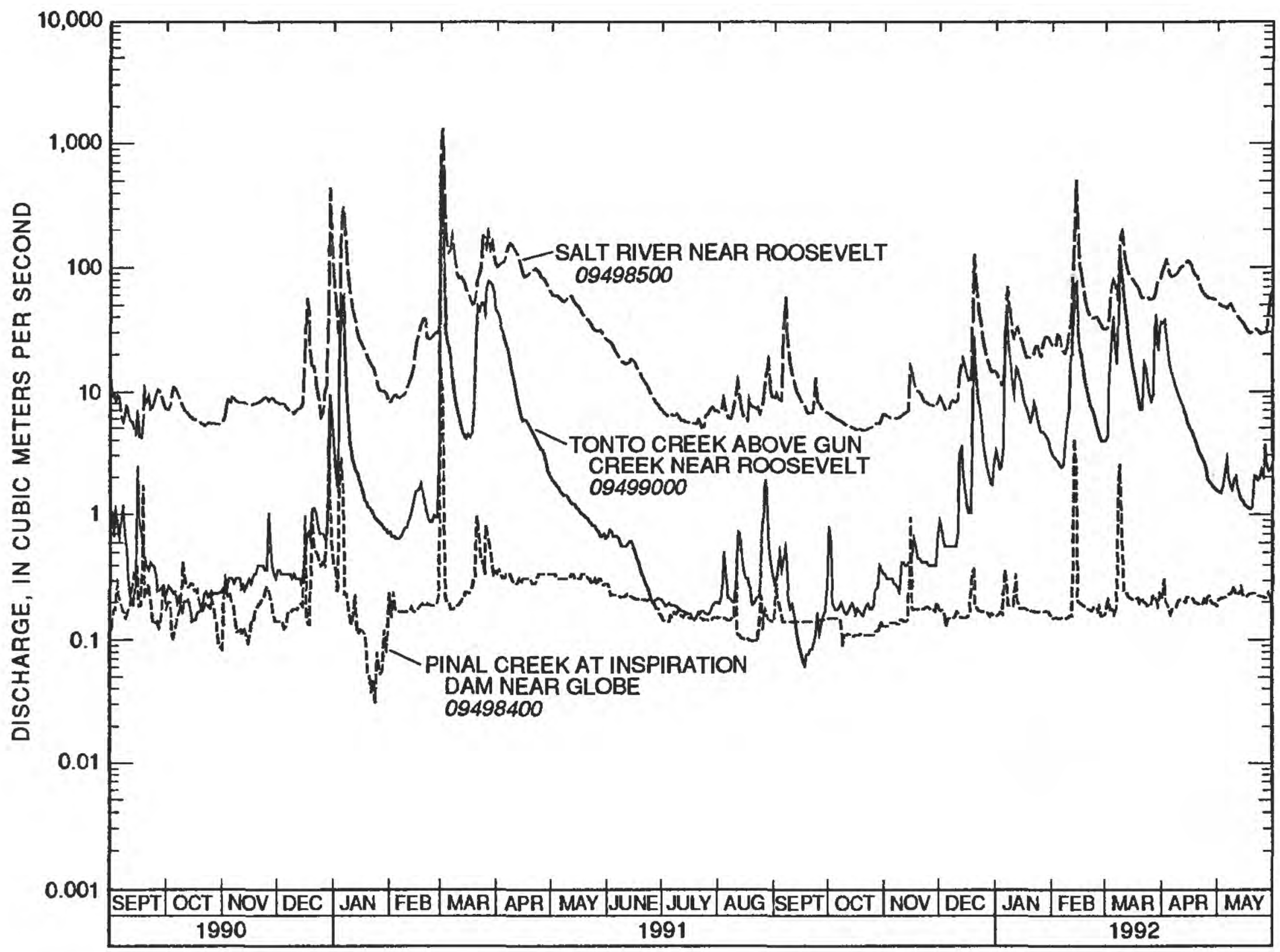

Figure 4. Stream discharges for Salt River, Tonto Creek, and Pinal Creek, Arizona, September 1990 through May 1992. U.S. Geological Survey streamflow-gaging station number is in italics. 
average discharge was $4.3 \mathrm{~m}^{3} / \mathrm{s}$ and the median of yearly mean discharges was $2.6 \mathrm{~m}^{3} / \mathrm{s}$ for the 50 -year period (water years) 1942-91 (Boner and others, 1992). The maximum discharge was $1,739 \mathrm{~m}^{3} / \mathrm{s}$ in February 1980 (Boner and others, 1992). Tonto Creek had periods of no flow during 1940-91 owing to infiltration of water into the alluvium. Base discharge in 1990 was $48 \mathrm{~m}^{3} / \mathrm{s}$ (Boner and others, 1992).

\section{Approach and Methods}

\section{Lake Measurements and Sample Collection}

During the limnological reconnaissance in 1990-92, samples were collected from each layer of the lake and analyzed for total nutrients and dissolved metals. Layers were defined by physical and chemical field data, primarily temperature and dissolved-oxygen concentration. Prior to collection of water-chemistry samples, vertical profiles were made of temperature, $\mathrm{pH}$, specific conductance, and dissolved-oxygen concentration. Secchi-disc readings were measured using a 25.4-centimeterdiameter, black and white disc. Lake-bottom sediments were analyzed for metal concentrations and the results compared with concentrations in the water.

Sets of samples were collected on the basis of lake stratification-three during stratification (April and August 1991 and May 1992); one during turnover (December 1991); one during high inflow (March 1992); and one before turnover (September 1990). Samples were collected for analysis from three sites in the lake - one in the Salt bay (Salt bay), one on the Tonto Creek arm (Tonto arm), and one adjacent to the dam (forebay).

Depths sampled during stratification were used as a guide in sampling during turnover and transitional conditions in order to determine the effects of stratification on the water chemistry. Data from a multiparameter instrument, which measured temperature, $\mathrm{pH}$, specific conductance, and dissolved-oxygen concentration, were used to determine the lake layers. Three locations were sampled within a vertical (one sample from each layer of the lake) - the hypolimnion (bottom), the metalimnion (middle), and the epilimnion (top).
Two different sample-collection techniques were used for sampling the lake during the study. Prior to August 1991, water was collected using a peristaltic pump and teflon tubing hooked to a steel cable and lowered to the desired depth. To prevent contamination from the steel cable, a polyvinylchloride rod was attached to the anchor and the sampler intake was positioned about $1 \mathrm{~m}$ from the cable and anchor. From August 1991 through May 1992, water samples were collected using a Van Dom sampler instead of a pump. The Van Dom sampler is triggered by a messenger weight and uses a plastic 6-liter bottle to collect the water sample at a specific point.

The procedures used for sample processing were consistent throughout the study. Water samples collected for determination of dissolved constituents were passed through 0.1 -micron pore-size filters. Chemical preservation of these samples was done immediately after sample collection and all bottles were stored in coolers until analyzed.

Prior to August 1991, sediment samples were collected using a bottom-sediment sampler (BM-54) that was treated for the collection of sediment-metal samples. The BM-54 is a 45-kilogram grab-sampling device that collects the top $5 \mathrm{~cm}$ of sediment. From August 1991 through May 1992, sediment samples were collected using a Wildco corer fitted with a plastic liner. The corer enabled the collection of sediment samples $5 \mathrm{~cm}$ in diameter and as much as $60 \mathrm{~cm}$ in depth. Regardless of the sample-collection device, the samples were placed in a teflon sieve and separated by particle size. Sediments less than $2 \mathrm{~mm}$ in diameter were sent to the ADHS laboratory for analysis of metals. Sediment samples were collected at each water-chemistry site and at two additional sites on the Salt arm.

\section{Infiow and Outflow Measurements and Sample Collection}

The inflows, Salt River and Tonto Creek, and outflow, Roosevelt Dam were sampled during the same week as the lake except for May 1992 when Tonto Creek was sampled a week later because of weather conditions. Additional samples from the Salt River site were used for quality assurance and 
quality control. Duplicates of samples collected at this site for a national program were sent to the USGS national laboratory. The analyses of the original and duplicate samples were in agreement. The Salt River site and the Tonto Creek site were sampled using the equal-width-increment method (U.S. Department of the Interior, 1984). The water for the outflow sample was obtained from a hose on the outside of the powerhouse on the left bank below Roosevelt Dam.

\section{Laboratory Analyses}

The USGS National Water-Quality Laboratory analyzed water for dissolved inorganics, nutrients, chlorophyll $a$, chlorophyll $b$, and total and dissolved organic carbon. The ADHS analyzed water for total inorganics, dissolved solids, dissolved boron, and dissolved thallium, and analyzed bottom sediment for metals.

\section{Statistical Methods}

Summary statistics for all constituents that contained censored data (values that were less than detection limits) were calculated using robust methods. These methods combine observed data above detection limits with below-limit values extrapolated, assuming a distributional shape (Helsel, 1990).

Linear- and logarithmic-regression analyses were done on the SRP data set to determine the level of confidence in conservative ions, which are used in calculations of metals loading. Because discharge measurements were not made during the SRP water-chemistry sampling, USGS daily mean discharges were used in the calculations. In setting parameters for the regression analyses, discharge was the independent variable and concentration was the dependent variable. The validity of the regression is measured using coefficient of determination $\left(\mathrm{r}^{2}\right)$ values, which range from 0 to 1 with 1 being optimal. Initially, linear regressions were done for the Salt River and Tonto Creek data using concentrations of dissolved solids, bicarbonate, chloride, and sodium; however, $\mathrm{r}^{2}$ values were less than 0.57 . Selected data points were then used to determine if a relation existed between low-flow discharges and concentrations.
Although several statistically significant relations were found, this approach was not practical because the mean discharges were greater than the discharges in the data set. Finally, a semilog-regression analysis was applied using the logarithm of the discharge and the concentration.

\section{HISTORICAL OVERVIEW}

Major studies of Roosevelt Lake have been done by the SRP, USEPA, ADEQ, and Arizona State University (ASU) (fig. 5). Unless otherwise noted, interpretations of data from the SRP and USEPA were done by the USGS; interpretations of data from the ADEQ, ASU, and other studies were taken from published reports. Almost all historical data collected by State and local agencies were surface grab samples rather than samples collected from various depths in Roosevelt Lake.

\section{Salt River Project Data}

The SRP collected and analyzed grab samples from 1980 through 1990 for nutrients, major ions, and metals. The data set included water chemistry from Roosevelt Lake, the tailrace, the penstock, Salt River inlet, and Tonto Creek (Greg Elliot, Principal Environmental Scientist, Salt River Project, written commun., 1991). This section of the report presents the USGS interpretation of the SRP data.

Major-ion concentrations indicate that Roosevelt Lake is chemically influenced more by the Salt River than by Tonto Creek (fig. 6). Of the major ions analyzed, the sodium-plus-potassium concentration was 13 percent in Tonto Creek and 35 percent in the Salt River compared with 35 percent in Roosevelt Lake, 29 percent in the penstocks, and 31 percent in the tailrace. The greatest major-ion concentrations in Tonto Creek were calcium and carbonate; the greatest major-ion concentrations in the Salt River, Roosevelt Lake, the penstocks, and the tailrace were sodium and chloride. The lake water has been slightly influenced chemically by Tonto Creek, as indicated by the percentages of the bicarbonate concentration.

The semilog-regression analysis for discharges from the Salt River resulted in a moderate $r^{2}$ value 


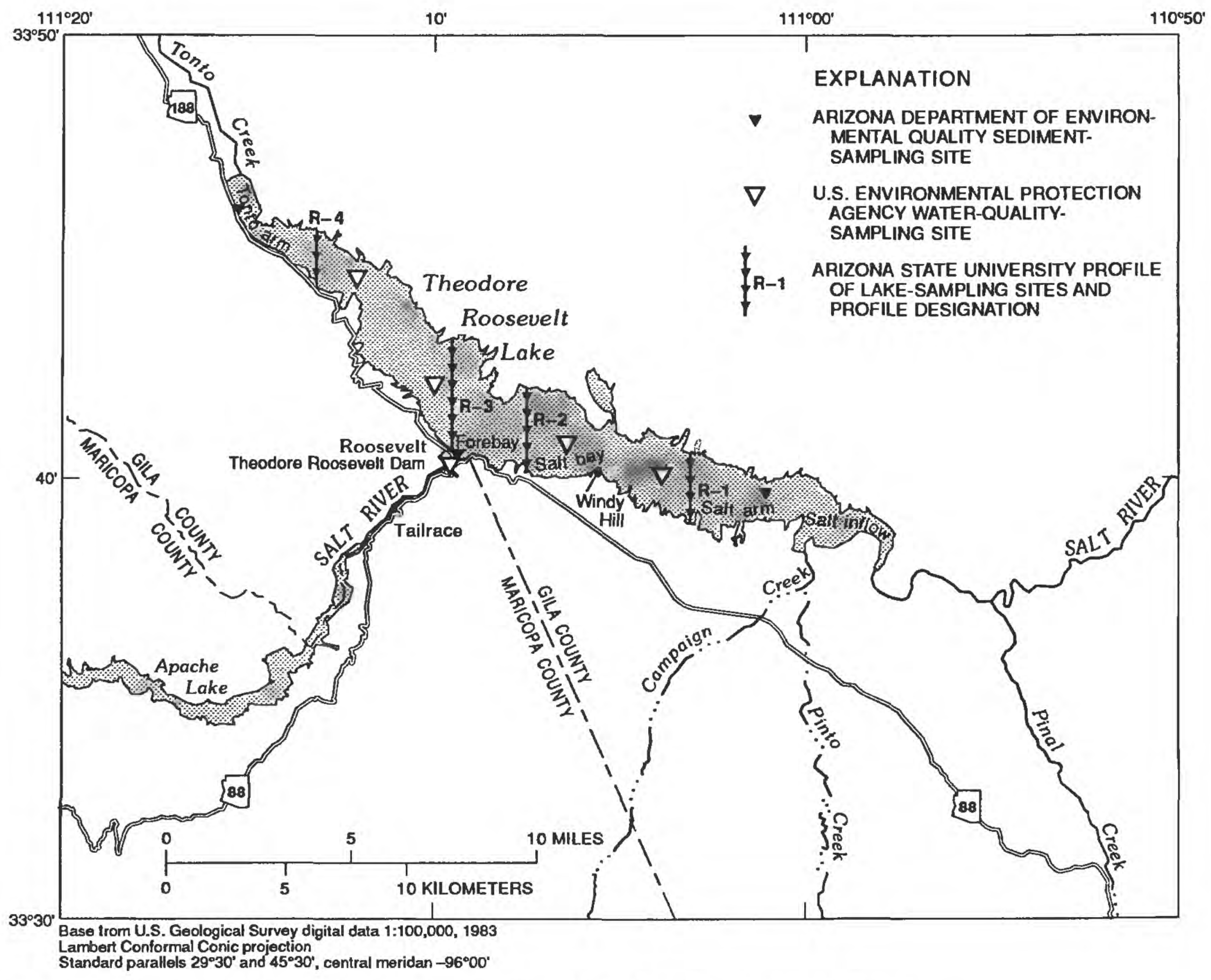

Figure 5. Location of historical data-collection sites at Theodore Roosevelt Lake, Arizona.

of 0.79 for chloride and 0.73 for sodium. However, the predictive power is nil because the slope of the regression is not significantly different from zero. The greatest $r^{2}$ value for discharges from Tonto Creek was for bicarbonate $\left(r^{2}=0.18\right)$. A log-log-regression analysis was applied; however, no significant relations were found for either site. The regression analysis of discharge from the Salt River and Tonto Creek and the chloride concentration from the penstocks resulted in a small $r^{2}$ value of 0.06 , indicating that discharge of stream inputs is not a good predictor of water chemistry leaving the dam. Regression analysis was not consistent enough to warrant calculations of metal loads.

\section{U.S. Environmental Protection Agency Studies}

The USEPA has created guidelines for determining the trophic status of lakes. Trophic status is determined by nutrient and chlorophyll-a concentrations and by Secchi-disc depth, all of which indicate the level of productivity of the lake (criteria for classification are given in tables 2 and 5). Eutrophic waters are nutrient rich, productive, and lead to lake senescence. Oligotrophic lakes are nutrient poor and mesotrophic lakes are intermediate in nutrient content.

The National Eutrophication Survey done in 1975 by the USEPA (U.S. Environmental 

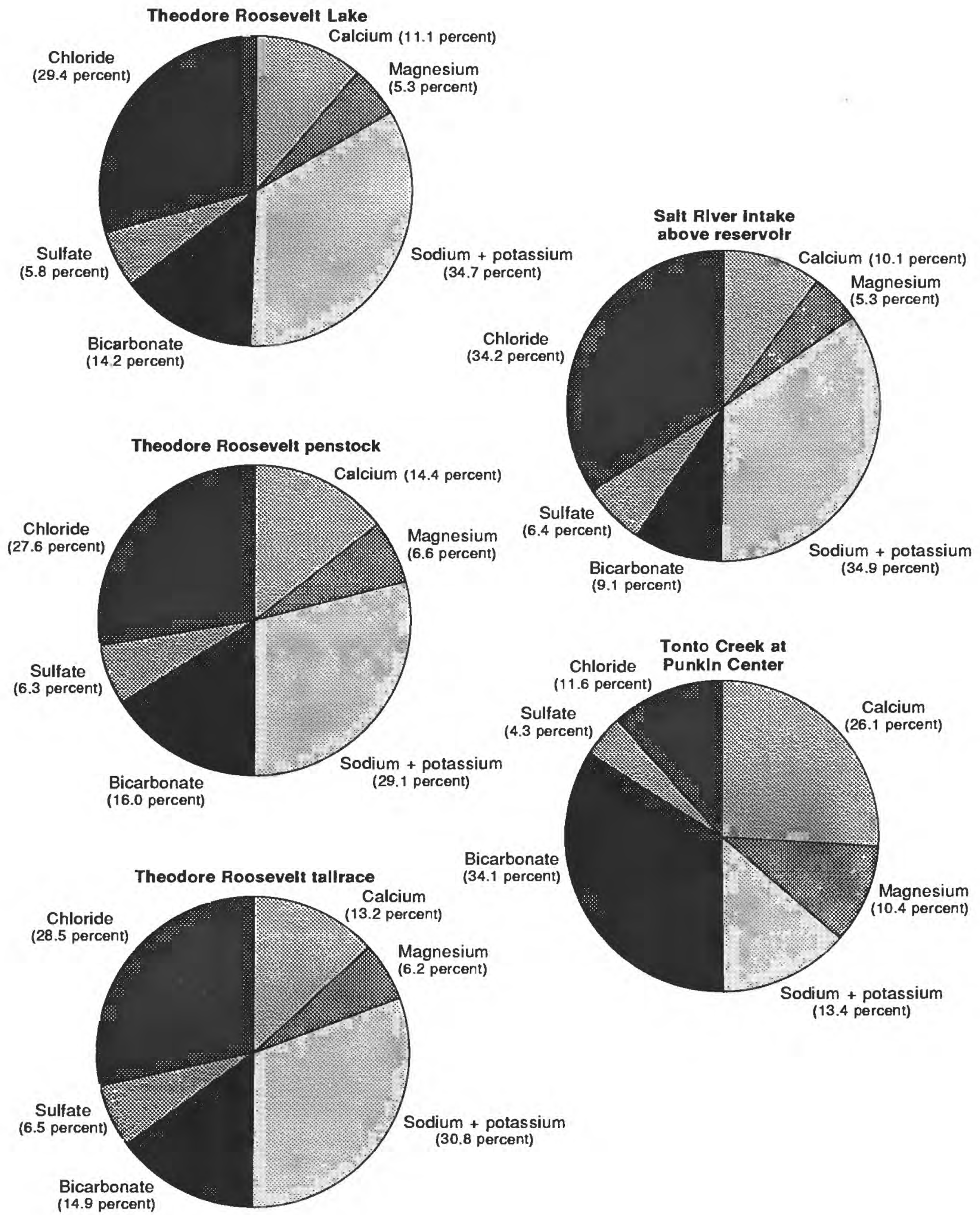

Figure 6. Major constituent distribution in water from the Theodore Roosevelt Lake area, Arizona, 1980 through 1990. (Source: Data from the Salt River Project.) 
Protection Agency, 1977) was a nutrient study at Roosevelt Lake involving the collection and analyses of nine municipal waste-water samples, five lake samples from various depths, and seven tributary samples (referred to as 1975 data in this report). The results of the survey indicated that Roosevelt Lake could be classified as a mesotrophic lake. The USGS calculated summary statistics of Secchi-disc depths and concentrations of chlorophyll $a$ and total phosphorous using the USEPA data (table 2). The mean total-phosphorus concentration and Secchi-disc depths indicated eutrophy, and the mean chlorophyll- $a$ concentration indicated oligotrophy. The report stated that primary nutrient limitation by nitrogen occurred during sampling; however, the report also stated that the algal assay test presented conflicting information. The algal assay test indicated that the addition of phosphorus alone stimulated algal production more than addition of nitrogen alone, but that the addition of phosphorus and nitrogen together produced algal yields an order of magnitude greater than yields from phosphorus alone.

Table 2. Statistical summary of nutrient data for Theodore Roosevelt Lake, Arizona, from the U.S. Environmental Protection Agency, 1975

[Data from U.S. Environmental Protection Agency (1977, p. 20)]

\begin{tabular}{|c|c|c|c|c|c|c|}
\hline $\begin{array}{l}\text { Site and diatance } \\
\text { upstream from tha dam }\end{array}$ & $\begin{array}{l}\text { Number of } \\
\text { aamplea }\end{array}$ & Median & Mean & $\begin{array}{l}\text { Standard } \\
\text { devlation }\end{array}$ & Minimum & Maximum \\
\hline 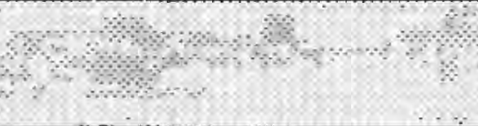 & \multicolumn{6}{|c|}{$\begin{array}{l}\text { Secchi-disc depth, in meters } \\
\text { (\$3.7 m, oligotrophic; } 2.0-3.7 \mathrm{~m} \text {, mesotrophic; }<2.0 \mathrm{~m} \text {, eutrophic) })^{1}\end{array}$} \\
\hline Salt arm, $10 \mathrm{~km}$ & 2 & -- & 1.4 & 0.21 & 1.2 & 1.6 \\
\hline Salt bay, $5.5 \mathrm{~km}$ & 2 & -- & 2.1 & .02 & 2.1 & 2.1 \\
\hline Tonto $\mathrm{arm}, 3 \mathrm{~km}$ & 3 & 2.1 & 1.9 & .35 & 1.5 & 2.1 \\
\hline Tonto arm, $9 \mathrm{~km}$ & 3 & 1.5 & 1.5 & .38 & 1.1 & 1.8 \\
\hline Forebay, $0.2 \mathrm{~km}$ & 2 & -- & 2.1 & .07 & 2.0 & 2.1 \\
\hline \multicolumn{7}{|c|}{$\begin{array}{c}\text { Chlorophyll-a concentrations, in micrograms per liter } \\
(<7 \mu \mathrm{g} / \mathrm{L}, \text { oligotrophic; } 7-12 \mu \mathrm{g} / \mathrm{L}, \text { mesotrophic; }>12 \mu \mathrm{g} / \mathrm{L} \text {, eutrophic })^{2}\end{array}$} \\
\hline Salt arm, $10 \mathrm{~km}$ & 3 & 4.0 & 4.5 & 1.04 & 3.8 & 5.7 \\
\hline Salt bay, $5.5 \mathrm{~km}$.................. & 3 & 4.0 & 4.9 & 1.65 & 3.9 & 6.8 \\
\hline Tonto arm, $3 \mathrm{~km}$ & 3 & 3.6 & 3.6 & .35 & 3.3 & 4.0 \\
\hline Tonto arm, 9 km ................. & 3 & 4.0 & 3.9 & .12 & 3.8 & 4.0 \\
\hline Forebay, $0.2 \mathrm{~km}$ & 3 & 2.7 & 3.4 & 1.57 & 2.3 & 5.2 \\
\hline \multicolumn{7}{|c|}{$\begin{array}{l}\text { Total phosphorus as } P, \text { in milligrams per liter } \\
(\leqslant 0.010 \mathrm{mg} / \mathrm{L} \text {, oligotrophic; } 0.010-0.020 \mathrm{mg} / \mathrm{L}, \text { mesotrophic; }>0.020 \mathrm{mg} / \mathrm{L} \text {, eutrophic })^{2}\end{array}$} \\
\hline Salt arm, $10 \mathrm{~km}$.................. & 15 & .02 & .02 & .01 & .01 & .05 \\
\hline Salt bay, $5.5 \mathrm{~km}$ & 16 & .02 & .02 & .01 & .01 & .03 \\
\hline Tonto arm, $3 \mathrm{~km}$.................. & 21 & .02 & .02 & .01 & .01 & .07 \\
\hline Tonto arm, $9 \mathrm{~km}$ & 15 & .02 & .02 & .00 & .02 & .04 \\
\hline Forebay, $0.2 \mathrm{~km}$ & 16 & .02 & .03 & .02 & .01 & .10 \\
\hline
\end{tabular}

${ }^{1}$ U.S. Environmental Protection Agency (1974).

${ }^{2}$ Arizona Game and Fish Department (1982-83). 
Nutrient loadings from point and nonpoint sources were determined in 1975 by the USEPA (table 3). Of the $126,490 \mathrm{~kg} / \mathrm{yr}$ of phosphorus entering Roosevelt Lake, the net annual phosphorus accumulation was 82 percent. Of the $678,060 \mathrm{~kg} / \mathrm{yr}$ of nitrogen entering the lake, the net annual nitrogen accumulation was 41 percent (U.S. Environmental Protection Agency, 1977). During 1975, the point sources, such as municipalities, contributed approximately 12 percent of the total-phosphorus load and 6.9 percent of the total-nitrogen load entering the lake. Nonpoint sources contributed approximately 88 percent of the total-phosphorus load and 94 percent of the total-nitrogen load entering the lake. The study estimated the phosphorus loading to be 2.08 grams per square meter per year. Sources for nitrogen loads were not determined by the USEPA. According to Vollenweider (1975), Roosevelt Lake was classified as an eutrophic lake on the basis of annual total-phosphorus loading. Concentrations of naturally occurring phosphorus, however, are high in some soils and water in Arizona.

The National Dioxin Study was developed by the USEPA (U.S. Environmental Protection
Agency, 1986) to determine the extent of dioxin contamination nationwide. The most toxic isomer of dioxin is 2,3,7,8-tetrachlorodibenzo-p-dioxin (2,3,7,8-TCDD), a contaminant used in the manufacture of trichlorophenol, which is the most potent animal carcinogen identified by the USEPA. One of the areas investigated during the study was a group of helipad sites in the Pinal Creek drainage basin where the herbicides 2,4,5-trichlorophenoxyacetic acid; 2,4-dichlorophenoxyacetic acid; and silvex were loaded on helicopters and then applied to more than 1,000 ha of the surrounding area during 1965-66 and 1968-69. Soil samples collected at five helipads, sediment samples obtained from nearby streams, tissue samples from several wildlife species (coyote, deer, frog, javelina, quail, snake, and toad), and a sunfish-tissue sample from a local stock tank were analyzed for 2,3,7,8-TCDD (U.S. Environmental Protection Agency, 1986). Dioxin was detected in soil samples from three of the helipads but was not detected in stream sediment or wildlife or fish tissues. One of the soil samples contained the greatest amount of 2,3,7,8-TCDD

Table 3. Total-nutrient loading of Theodore Roosevelt Lake, Arizona, 1975

[Data from U.S. Environmental Protection Agency (1977, p. 15-16)]

\begin{tabular}{|c|c|c|c|c|}
\hline \multirow[b]{2}{*}{ Inputs/Outputs } & \multicolumn{2}{|c|}{ Phosphorus } & \multicolumn{2}{|c|}{ Nitrogen } \\
\hline & $\begin{array}{l}\text { Kilograms } \\
\text { per year }\end{array}$ & $\begin{array}{c}\text { Percent } \\
\text { (approximate) }\end{array}$ & $\begin{array}{c}\text { Kilograms } \\
\text { per year }\end{array}$ & $\begin{array}{c}\text { Percent } \\
\text { (approximale) }\end{array}$ \\
\hline \multicolumn{5}{|l|}{ Inputs } \\
\hline \multicolumn{5}{|l|}{ Tributaries } \\
\hline Salt River .................................. & 104,680 & 83 & 473,010 & 70 \\
\hline 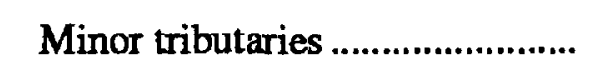 & 5,700 & 4.5 & 92,275 & 14 \\
\hline Municipalities .............................. & 15,050 & 12 & 47,245 & 6.9 \\
\hline Direct precipitation ...................... & 1,060 & 0.8 & 65,530 & 9.7 \\
\hline 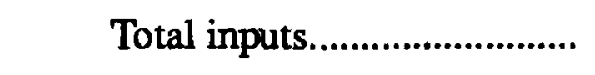 & 126,490 & 100 & 678,060 & 100 \\
\hline \multicolumn{5}{|l|}{ Outputs } \\
\hline Salt River ...................................... & 22,380 & 18 & 401,180 & 59 \\
\hline Net annual accumulation ............... & 104,110 & 82 & 276,880 & 41 \\
\hline
\end{tabular}


reported for any herbicide-use area sampled during the national study.

\section{Arizona Department of Envlronmental Quality Studies}

The ADEQ and the U.S. Fish and Wildlife Service (USFWS) collected one fish-tissue composite and three sediment samples from Roosevelt Lake as part of the statewide priority pollutants sampling program in 1989 (Arizona Department of Environmental Quality, 1991). This sampling program was part of a multi-agency effort to screen surface waters for 126 priority pollutants. Constituents detected in the fish-tissue sample included 4,4-dichloro diphenyl dichloroethylene (DDE), chromium, nickel, and zinc. Only DDE was present at concentrations greater than the
USEPA-recommended fish-tissue concentration. Constituents detected in the three sediment samples included antimony, arsenic, beryllium, chromium, copper, lead, nickel, and zinc (table 4). The antimony concentration $(50.8 \mu \mathrm{g} / \mathrm{g})$ in the sediment sample collected at Roosevelt Dam (forebay) exceeded the Ingestion Health-Based Guidance Level (IHBGL) recommended by the State of Arizona $(47 \mathrm{mg} / \mathrm{kg}$ or $47 \mu \mathrm{g} / \mathrm{g}$ ) (Arizona Department of Environmental Quality, 1992d). The beryllium concentration in sediments from all three sites exceeded the IHBGL $(0.32 \mathrm{mg} / \mathrm{kg})$. Pesticides were not detected in the three sediment samples. Concentrations of metals on the sediment generally were greatest for the forebay and least for the Salt bay. Copper concentrations were $87.5 \mu \mathrm{g} / \mathrm{g}$ for the Salt inflow, $84.5 \mu \mathrm{g} / \mathrm{g}$ for the forebay, and $39.5 \mu \mathrm{g} / \mathrm{g}$ for the Tonto arm.

Table 4. Sediment-metal concentrations at Theodore Roosevelt Lake, Arizona, 1989

[Data from Arizona Department of Environmental Quality (1991); J, indicates that the results are considered estimates and the data are valid for limited purposes, results are qualitatively acceptable; $U$, indicates that the constituent is not detected above the concentration listed; $L_{r}$ indicates results that fall between the instrument detection limit for waters or the method detection limit for soils and the contract required quantitation limit, results are considered estimates and usable for limited purposes]

\begin{tabular}{|c|c|c|c|c|c|c|c|c|}
\hline Constltuent & \multicolumn{2}{|c|}{ Forebsy } & \multicolumn{2}{|c|}{ Ssit Inflow } & \multicolumn{2}{|c|}{ Tonto srm } & \multicolumn{2}{|c|}{ Laboratory blank } \\
\hline \multicolumn{9}{|c|}{ Concentrations, in micrograms per gram } \\
\hline 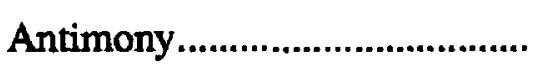 & 50.8 & $\mathbf{J}$ & 17.3 & $\mathbf{U}$ & 21.5 & $\mathrm{U}$ & 12.6 & \\
\hline 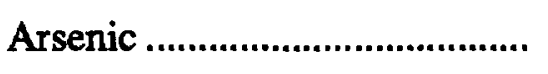 & 16.3 & & 6.4 & & 14.2 & & .4 & $\mathrm{U}$ \\
\hline 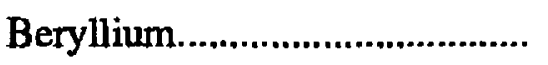 & 2.1 & $\mathrm{~L}, \mathbf{J}$ & 1.1 & $\mathrm{~L}$ & 1.2 & $\mathrm{~L}$ & .3 & \\
\hline 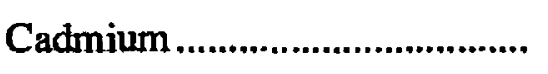 & 3.3 & $\mathrm{U}$ & 1.4 & $\mathbf{U}$ & 1.7 & $\mathbf{U}$ & .8 & $\mathrm{U}$ \\
\hline 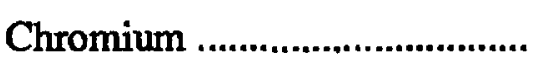 & 27.8 & & 19.4 & & 23.2 & & .8 & $\mathrm{U}$ \\
\hline 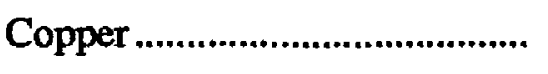 & 84.5 & & 87.5 & & 39.5 & & 1.2 & $\mathrm{U}$ \\
\hline 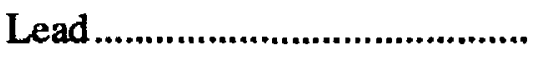 & 22.3 & & 10.9 & & 17.9 & & .4 & $\mathrm{U}$ \\
\hline Mercury & .62 & $\mathrm{U}$ & .30 & & .32 & $\mathrm{U}$ & .15 & $\mathrm{U}$ \\
\hline 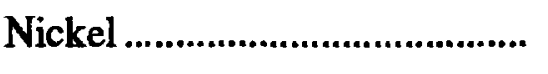 & 55.7 & & 35.7 & & 42.5 & & 2.4 & L, J \\
\hline 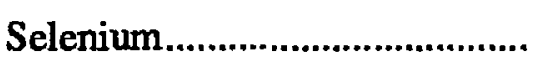 & 1.7 & U & .7 & $\mathbf{U}$ & .9 & $\mathrm{U}$ & .4 & $\mathrm{U}$ \\
\hline 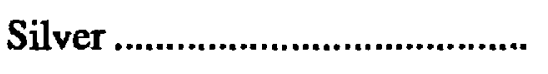 & 8.3 & $\mathrm{U}$ & 3.5 & $\mathbf{U}$ & 4.3 & $\mathrm{U}$ & 2.0 & $\mathrm{U}$ \\
\hline 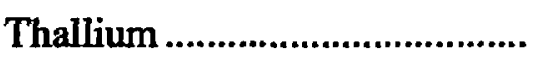 & 1.7 & $U$ & .7 & $U$ & .9 & $U$ & .4 & $U$ \\
\hline Zinc & 85.2 & & 53.6 & & 66.2 & & 2.0 & $\mathbf{U}$ \\
\hline
\end{tabular}


The ADEQ collected three water samples from Roosevelt Lake as part of the statewide Ambient Toxicity Testing program in April 1991 (Arizona Department of Environmental Quality, 1992b). The goal of the program was to use aquatic organisms to determine the toxic effects of polluted waters. Samples from Roosevelt Lake were collected at depths of 1,10 , and $30 \mathrm{~m}$ and submitted for a 48-hour acute toxicity test using the organism Daphnia magna. No mortality of Daphnia magna occurred in the three lake samples.

According to ADEQ Compliant Investigations, a complaint was filed against Inspiration Consolidated Copper Company for discharges into Miami Wash near Miami, Arizona, (fig. 2) after the 18-inch-diameter main tailings line ruptured on October 30, 1984. Flows reached Miami Wash in a slurry. Water-chemistry data were not collected.

In 1991, a complaint was filed about a rotten-egg smell at the mouth of Pinal Creek. Analysis of water samples from the beginning of perennial flow, from the mouth of Pinal Creek at the Salt River, and from two sites on Pinal Creek upstream from the mouth indicated gradients in $\mathrm{pH}$ and in metal concentrations. Water from the most upstream site had a $\mathrm{pH}$ of 5.9 and contained $72 \mathrm{mg} / \mathrm{L}$ of manganese, $0.76 \mathrm{mg} / \mathrm{L}$ of nickel, and $0.055 \mathrm{mg} / \mathrm{L}$ of copper. Water from downstream sites had near-neutral $\mathrm{pH}$ and lesser concentrations of metals. According to the ADEQ, the color of the water at the upstream site was black, apparently because of the concentration of manganese in the water. The greater manganese concentration was attributed to scouring of the channel upstream as a result of either increased flows in Pinal Creek or disturbance from reconstruction of an earthen dam upstream (Patricia Spindler, Aquatic Biologist, Arizona Department of Environmental Quality, written commun., 1993).

In 1993, a complaint was filed regarding unnaturally blue- or turquoise-colored water at the Bixby Road seep near the lower part of Miami Wash. The $\mathrm{pH}$ measured at Bixby Road seep was 4.7 , which is more acidic than the 6.5 water-quality standard for surface water (Arizona Department of Environmental Quality, 1992c). In the perennial reach of Pinal Creek, which is $2.4 \mathrm{~km}$ downstream, $\mathrm{pH}$ had increased 3 units, flow had increased fivefold, and conductivity was reduced by half. According to the ADEQ, the acidic Bixby Road seep water was being diluted by less polluted ground water flowing into the Pinal Creek channel and as the water was oxidized, the $\mathrm{pH}$ was neutralized and copper was deposited on stream sediments. Efforts by the Pinal Creek Group, a mining company association, to contain the Bixby Road seep and other nearby seeps were recognized by the ADEQ and no enforcement actions were deemed necessary (Patricia Spindler, Aquatic Biologist, Arizona Department of Environmental Quality, written commun., 1993).

\section{Arizona State University Study}

In 1970-71, physical, chemical, and biological data for the Salt River reservoirs were collected by Rinne (1973), and the production and dispersion of fishes among the impoundments were determined. The purpose of this comprehensive study was to identify the significant abiotic and biotic factors that affect fish production and dispersion.

According to Rinne (1973), Roosevelt Lake is classified as a warm monomictic lake, being thermally stratified from April to November and mixed in late November to early December. The lake developed a thermocline at a depth of 4 to $6 \mathrm{~m}$ by June 1971. By August, the thermocline had reached a maximum depth of $15 \mathrm{~m}$. Release of water through the generator penstocks located in the hypolimnion contributed to the lowering of the thermocline. Water temperatures reached maximums in August and September.

During the study by Rinne, $\mathrm{pH}$, dissolved-oxygen concentrations, and specific conductance were measured. The $\mathrm{pH}$ ranged from 6.7 to 9.4 in Roosevelt Lake. Dissolved oxygen was above $5 \mathrm{mg} / \mathrm{L}$ in the lake except within the hypolimnion during the summer. Dissolvedoxygen saturation near the lake surface was high in the spring (greater than 100 percent), was less in the summer ( 65 to 85 percent), and increased again in the fall (90 to 110 percent). The greatest depletion of dissolved oxygen occurred below the thermocline during August and September. Dissolved oxygen was uniformly distributed in the hypolimnion in December. The specificconductance values gradually increased from April to August and attained a maximum in July, then dropped slightly in the fall, and attained a minimum 
in April. The winter decline was attributed to decreased evaporation and water demands and increased discharge of the Salt River. Specific conductance ranged from 1,300 to $1,500 \mu \mathrm{S} / \mathrm{cm}$.

Greater turbidity in the Salt and Tonto arms of the lake than in the central part of the lake was attributed to inflowing water and the stirring of nonstratified water by wind action in the more shallow parts of the arms. Turbidity in Roosevelt Lake ranged from 1 to 275 Jackson Turbidity Units (JTU) with a mean of 21 JTU. Roosevelt Lake serves as a settling basin for the Salt River reservoirs, intercepting and retaining silt from the Salt River and Tonto Creek and releasing silt during periods of high inflow. The ratio of the depth of the euphotic zone to Secchi-disc depth was 3.4 for all the Salt River reservoirs combined.

Phosphate values ranged from 0.01 to $2.8 \mathrm{mg} / \mathrm{L}$, indicating eutrophy. Nitrate values ranged from 0.01 to $0.70 \mathrm{mg} / \mathrm{L}$, indicating oligotrophy. Vertical profiles indicated little variation in phosphate concentrations with depth in Roosevelt Lake even during summer stratification. Phosphate concentrations were greater for the Tonto arm than for the Salt arm of Roosevelt Lake. No significant spatial patterns of nitrate were apparent. Nitrate was greatest in August and November and phosphate was greatest in April, August, and November. Neither nitrate nor phosphate concentrations approach a level that would be considered limiting in Roosevelt Lake except on very rare occasions. Chlorophyll values were greater at the Salt arm and Tonto arm than at the forebay. Chlorophyll- $a$ values ranged from 1 to $24 \mu \mathrm{g} / \mathrm{L}$, which were within the mesotrophic to eutrophic range. Secchi-disc depths were within the eutrophic range. These values may not be representative of normal conditions because the water level of the lake was low during the study.

The Salt River reservoirs contain about 40 species of fish, mostly nonnative. Largemouth bass (Micropterus salmoides) was the top camivore of Roosevelt Lake. Black crappie, (Pomoxis nigromaculatus), sunfish (genera Lepomis and Chaenobryttus), and catfish (Ictalurus punctatus) also are common in the Salt River reservoirs. Buffalofishes (Ictiobus sp.) and carp (Cyprinus carpio) are present in all four reservoirs and are locally abundant. Threadfin shad (Dorosoma petenense) was the primary forage fish. Food resources consisted of the clam (Corbicula), two species of crayfish, dipteran larvae, oligochaete worms, and a few aquatic insects other than dipterans. In terms of vertical distribution, most fish were found in the top $10 \mathrm{~m}$ of the water column during midday and 98 percent of all bass and shad collected were found above the thermocline.

Fish abundance was greatest in the Salt arm from August 1970 to April 1971 but was greater in the Tonto arm during August to November 1971. The central part of the lake west of Windy Hill (Salt bay) was the least productive. Schools of threadfin shad were found in greatest concentration over littoral areas and in coves. Greater food availability in the Salt arm and the influence of temperature, oxygen, and morphometry at the Salt bay site contributed to the greater fish abundance in the Salt arm. A strong correlation between chlorophyll- $a$ and fish densities suggests that primary production was least variable relative to fish concentrations but the benthos concentrations varied inversely to fish concentrations. Predator-prey species interactions, lake morphology, chlorophyll- $a$ concentrations, dissolved-oxygen concentrations, and water temperatures appeared to be the most important factors in determining the horizontal and vertical distribution of fish.

\section{Other Studies}

The Arizona Game and Fish Department (1982-83) conducted a water-sampling program at Roosevelt Lake from 1982 to 1983 at three sites. Physicochemical data were collected during July and December 1982 and March and May 1983. Thermal stratification was evident in July 1982. Dissolved-oxygen and temperature data indicated that Roosevelt Lake was not stratified in December 1982, March 1983, or May 1983.

The USFWS (1991) conducted a biomonitoring study of bald eagle diet items in 1988. The objective of the study was to determine ambient contaminant concentrations in prey items and to assess contaminant exposure to resident breeding eagles. Two (whole body) composite fish samples from the Salt River upstream from Pinal Creek and four composite fish samples from the Salt arm of Roosevelt Lake were analyzed for organochlorines and metals as part of the study. Organochlorine data showed that only DDE was detected in 
the fish-tissue samples from the Salt River compared with five organochlorines-DDE, dieldrin, trans-nonachlor, and alpha and gamma chlordane-detected in fish-tissue samples from Roosevelt Lake. The mean DDE concentration was greater in samples from Roosevelt Lake than in samples from the Salt River. Eleven metals were detected in the fish-tissue samples. On the basis of dry-weight analyses, concentrations of seven of the metals were greater in samples from Roosevelt Lake than in those from the Salt River.

The BOR collects weekly temperature data from seven thermocouples on the face of Roosevelt Dam and records the average daily elevations of Roosevelt Lake (Joel Sturm, Bureau of Reclamation, oral commun., 1992). A sediment survey was done in 1981 to calculate reservoir capacity and the volume of sediment that has accumulated since 1909 (Lara, 1982). The BOR resurveyed the area and calculated the surface area to be 7,016 ha and the total storage capacity to be $1,648 \mathrm{hm}^{3}$ (Lara, 1982). The loss of $239 \mathrm{hm}^{3}$ in storage capacity from 1909 to 1981 was due to the accumulation of sediments and represents an average accumulation rate of $3.29 \mathrm{hm}^{3} / \mathrm{yr}$ (Lara, 1982).

\section{RESULTS OF LIMNOLOGICAL RECONNAISSANCE, 1990-92}

\section{Physicochemical Stratification}

Physical and chemical analyses were done at three sites in the lake-Salt bay, Tonto arm, and forebay (fig. 7). During each sampling period, physicochemical data-temperature, $\mathrm{pH}$, dissolved oxygen, and specific conductance-were collected at each of the three sites.

Roosevelt Lake is a warm, monomictic (turning over once per year) reservoir (Rinne, 1973). The temperature among the three lake sites during the study ranged from $10.5^{\circ}$ to $30.5^{\circ} \mathrm{C}$, with a mean temperature of $19.7^{\circ} \mathrm{C}$. Results from this study indicate that Roosevelt Lake begins thermal stratification (developing three distinct layers, the epilimnion, the metalimnion, and the hypolimnion) in February and becomes strongly stratified by April. In May 1992, all three sites were thermally stratified (fig. 7) and the metalimnion was at a depth of from 5 to $20 \mathrm{~m}$. Stratified conditions remained through August, and by September the stratification was weakened. The lake appeared to be thermally mixed from October through December. The highest mean temperature $\left(28.5^{\circ} \mathrm{C}\right)$ was in August 1991 and was twice that of the lowest mean temperature $\left(13.8^{\circ} \mathrm{C}\right)$ in April and December 1991. Within the water column, the mean temperature of the epilimnetic water was $22.8^{\circ} \mathrm{C}$, the mean temperature of the metalimnetic water was $19.4^{\circ} \mathrm{C}$, and the mean temperature of the hypolimnetic water was $16.9^{\circ} \mathrm{C}$.

Areally, the Tonto arm appears to begin the process of turnover sooner than the Salt bay or the forebay (figs. 8-10). Consequently, the Tonto arm also begins thermal stratification before the other two areas of the lake. The reason for this difference is a combination of differences in depth and rate of inflow. The Tonto arm was the shallowest site sampled and was less affected by high-flow runoff than the Salt bay. The Salt bay and the forebay appear to begin thermal stratification at nearly the same time. The Salt bay is shallower than the forebay, but is more affected by runoff. The mean temperature $\left(19.3^{\circ} \mathrm{C}\right)$ of the forebay was lower than that of the two other sites $\left(19.9^{\circ} \mathrm{C}\right)$.

The $\mathrm{pH}$ for the three lake sites ranged from 7.2 to 8.6 and had a mean value of 7.9. During the Rinne (1973) study, the pH ranged from 6.7 to 9.4 . During the USGS study, the epilimnetic water had a greater mean $\mathrm{pH}$ value (8.3) than either the metalimnetic (7.9) or the hypolimnetic (7.6) water. Seasonally, the greatest mean $\mathrm{pH}$ value (8.1) was in August 1991; the least mean pH value (7.7) was in December 1991.

Specific-conductance ranged from 512 to $1,950 \mu \mathrm{S} / \mathrm{cm}$ and had a mean value of $1,014 \mu \mathrm{S} / \mathrm{cm}$ for the three lake sites. During the Rinne (1973) study, mean specific-conductance values ranged from 1,300 to $1,500 \mu \mathrm{S} / \mathrm{cm}$. During the USGS study, the mean specific-conductance value of the hypolimnetic water $(1,085 \mu \mathrm{S} / \mathrm{cm})$ was greater than that of the metalimnetic $(1,010 \mu \mathrm{S} / \mathrm{cm})$ or epilimnetic $(949 \mu \mathrm{S} / \mathrm{cm})$ water. Seasonally, the greatest mean specific-conductance value $(1,908 \mu \mathrm{S} / \mathrm{cm})$ was in September 1990 and was almost three times greater than the least mean value $(651 \mu \mathrm{S} / \mathrm{cm})$ that occurred in May 1992. Areally, the mean value for the Tonto arm $(1,058 \mu \mathrm{S} / \mathrm{cm})$ 


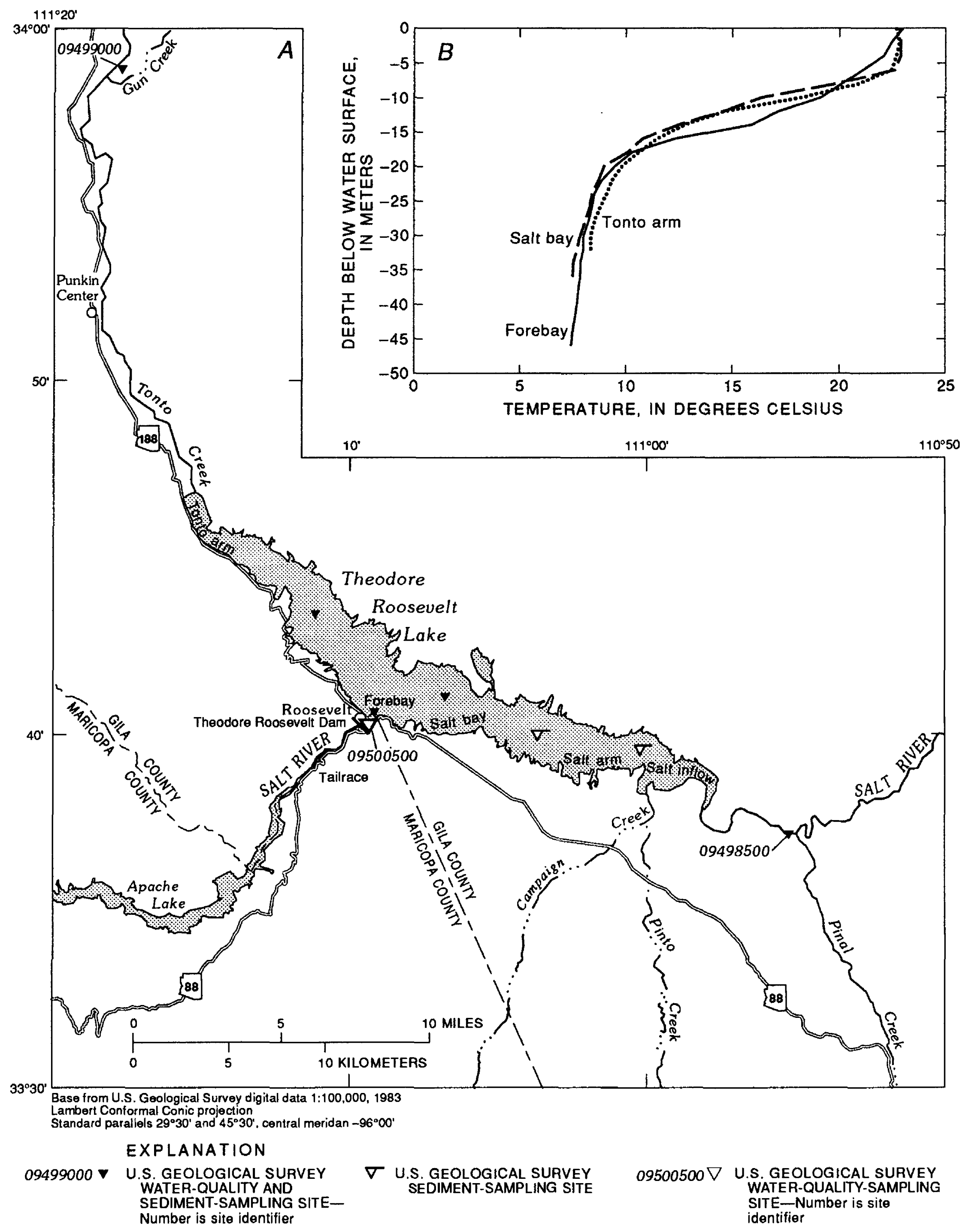

Figure 7. Data-collection sites and temperature profiles from the limnological reconnaissance at Theodore Roosevelt Lake, Arizona. A, Location of U.S. Geological Survey data-collection sites, 1990-92. B, Temperature profiles for sites at the forebay, Salt bay, and Tonto arm, May 1992. 

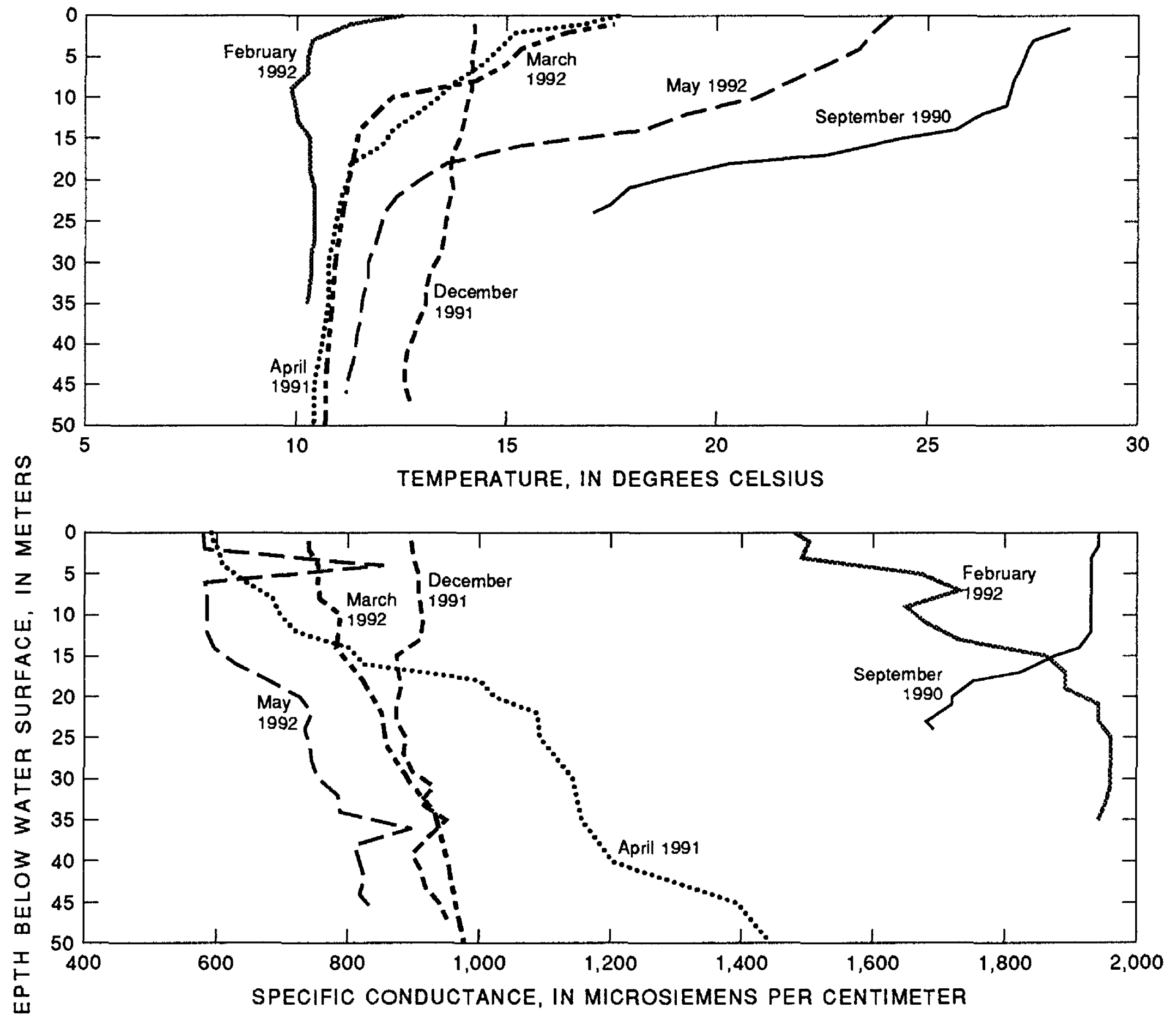

0

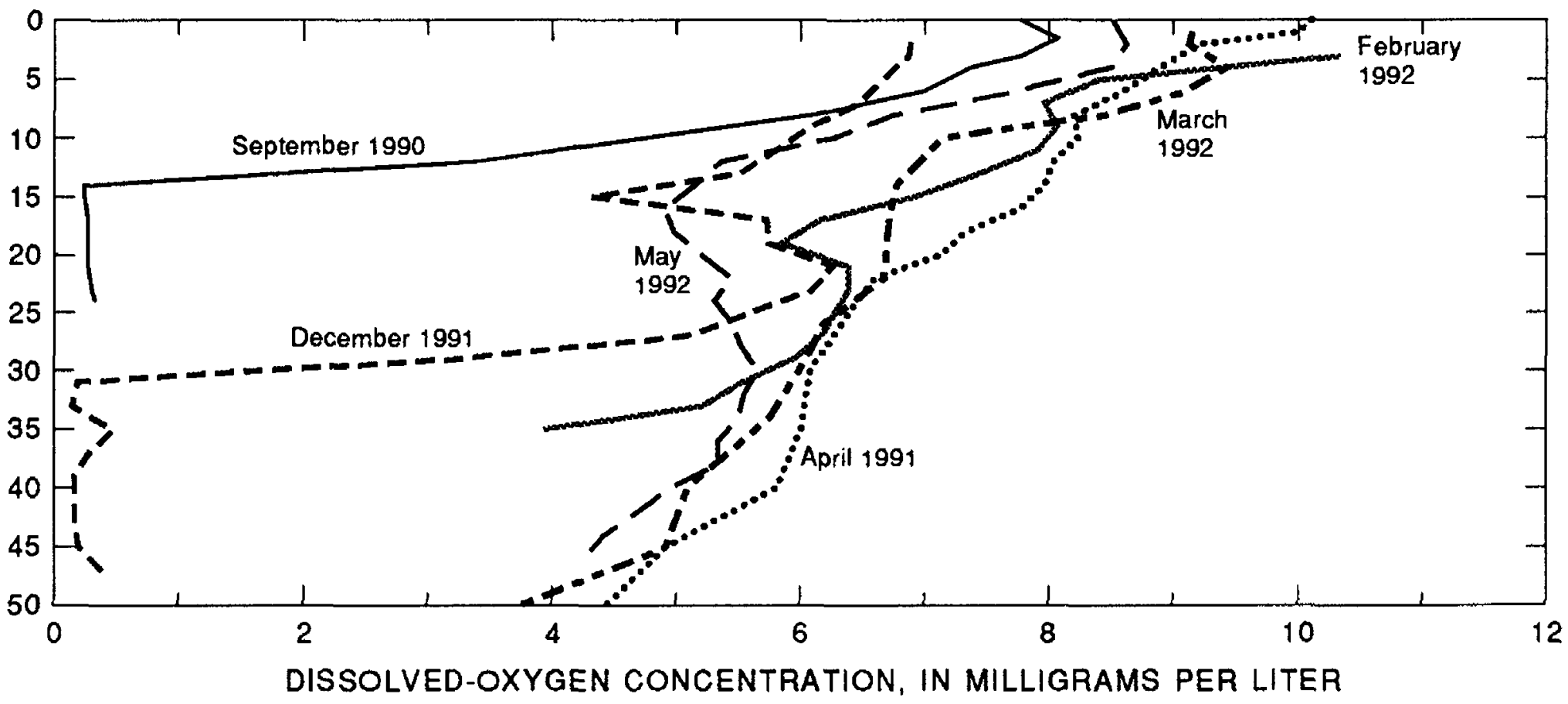

Figure 8. Temperature, specific conductance, and dissolved-oxygen values in the forebay, Theodore Roosevelt Lake, Arizona, September 1990 through May 1992. 

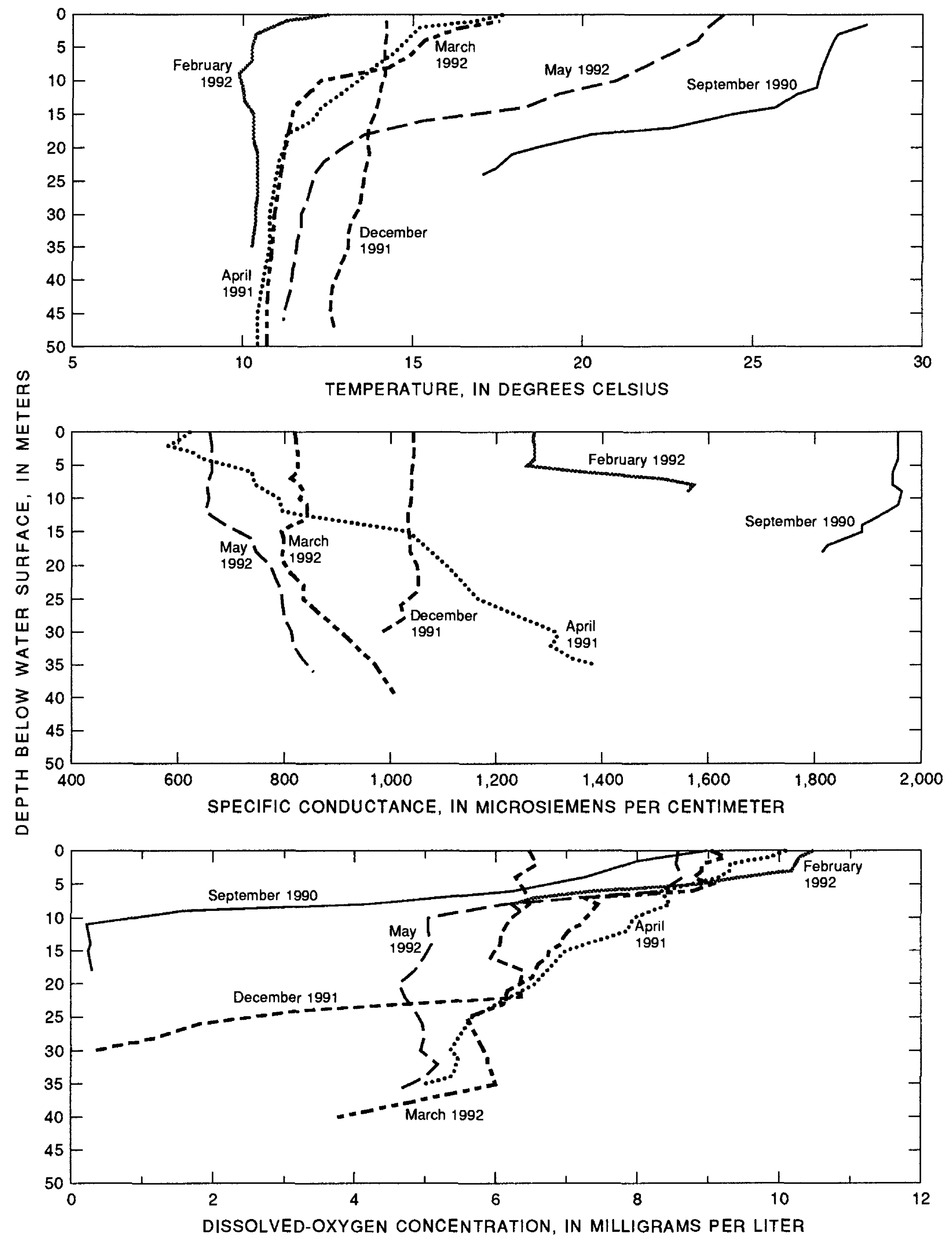

Figure 9. Temperature, specific conductance, and dissolved-oxygen values in the Salt bay, Theodore Roosevelt Lake, Arizona, September 1990 through May 1992. 


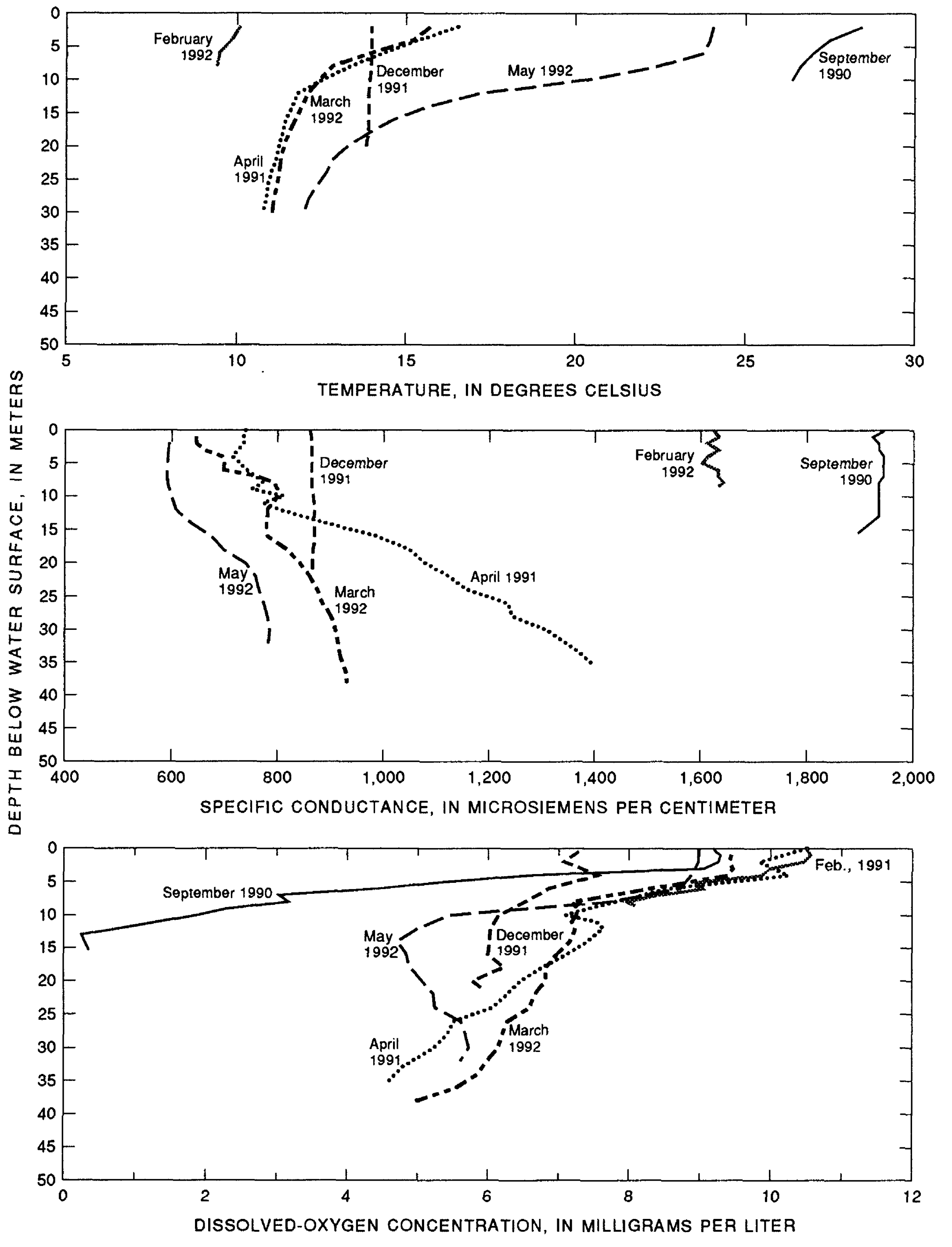

Figure 10. Temperature, specific conductance, and dissolved-oxygen values in the Tonto arm, Theodore Roosevelt Lake, Arizona, September 1990 through May 1992. 
was greater than the mean values for the Salt bay $(994 \mu \mathrm{S} / \mathrm{cm})$ and forebay $(988 \mu \mathrm{S} / \mathrm{cm})$. Although a change occurred in the specific conductance at the forebay in May 1992, this change did not occur at the other two sites in Roosevelt Lake. Therefore, no evidence existed of a developed chemocline during April 1991 or May 1992.

The dissolved-oxygen concentration ranged from 0.2 to $11.2 \mathrm{mg} / \mathrm{L}$ and had a mean of $6.2 \mathrm{mg} / \mathrm{L}$ for the three sites. Within the water column, the mean dissolved-oxygen concentration $(3.6 \mathrm{mg} / \mathrm{L}$ ) of the hypolimnetic water was less than that of either the metalimnetic $(6.2 \mathrm{mg} / \mathrm{L})$ or the epilimnetic $(8.8 \mathrm{mg} / \mathrm{L})$ water. Areally, the mean dissolved-oxygen concentration $(5.8 \mathrm{mg} / \mathrm{L})$ of the Salt bay was less than that of the other two sites $(6.4 \mathrm{mg} / \mathrm{L})$.

Ordinarily, when a lake or reservoir is mixed, dissolved oxygen will be replenished in the hypolimnion by atmospheric reaeration. Conversely, when the reservoir is strongly stratified, dissolved oxygen will decline because of consumption by respiration and decomposition processes. In December 1991, when Roosevelt Lake was thermally mixed, and in February 1992, a dissolved-oxygen minimum occurred in the metalimnion in conjunction with near anoxic conditions in the hypolimnion. In December 1991, the dissolved-oxygen concentration near the bottom of the lake was minimal except in the Tonto arm. Temperature and specific-conductance data indicated that thermal turnover was completed by December, but the dissolved-oxygen data were more indicative of a stratified condition. The mean dissolved-oxygen concentration for the lake was greatest in August $1991(8.0 \mathrm{mg} / \mathrm{L})$ and was least in September $1990(4.0 \mathrm{mg} / \mathrm{L})$.

Concentrations of manganese were elevated in the hypolimnion during turnover, probably as a result of the decrease in dissolved-oxygen concentrations. Manganese concentrations were elevated in the hypolimnion $(820 \mu \mathrm{g} / \mathrm{L}$ in September 1990 and $880 \mu \mathrm{g} / \mathrm{L}$ in December 1991) when the concentration of dissolved oxygen approached zero. Dissolved-oxygen concentrations decreased to near zero in the hypolimnetic waters in September 1990 and December 1991 at the forebay and Salt bay sites. The December values were anomalous because elevated dissolved-oxygen concentrations generally accompany equaltemperature conditions throughout the water column during turnover.

Transparency can affect the photosynthetic production of oxygen by its effect on the depth of penetration of photosynthetically active radiation. The changes in dissolved-oxygen concentration and specific conductance probably are light influenced (fig. 11).

\section{Water Chemistry}

Chemical analyses were done on samples from the three lake sites (Salt bay, Tonto arm, and forebay) and from the Salt River, Tonto Creek, and the outflow from the dam. The lake limnology is characterized in the following sections that discuss the trophic status of the lake and selected chemical and physical components of water from the lake and streams. Water samples from the three lake sites and three stream sites were analyzed for concentrations of nutrients, major ions, and dissolved metals.

\section{Trophic Status}

The trophic condition is commonly defined by concentrations of phosphorus, chlorophyll $a$, and Secchi-disc depth. Using data collected during this study, however, Roosevelt Lake could be classified as eutrophic (on the basis of mean Secchi-disc depths and mean total-phosphorus concentrations), oligotrophic (on the basis of mean chlorophyll-a concentrations) (table 5). Although these classifications differ overall, Roosevelt Lake is classified as mesotrophic.

Chlorophyll- $a$ values provide a biological measurement of the primary productivity, as biomass, of the lake. During this study, chlorophyll- $a$ concentrations ranged from 0.70 to $14 \mu \mathrm{g} / \mathrm{L}$, and the mean concentration was $2.8 \mu \mathrm{g} / \mathrm{L}$. According to the classification scheme of the Arizona Game and Fish Department (1982-83), the mean concentration indicates oligotrophy. Chlorophyll- $a$ concentrations during the 1975 study by the USEPA ranged from 2.3 to $6.8 \mu \mathrm{g} / \mathrm{L}$, and the mean concentration was $4.1 \mu \mathrm{g} / \mathrm{L}$ (U.S. Environmental Protection Agency, 1977). 


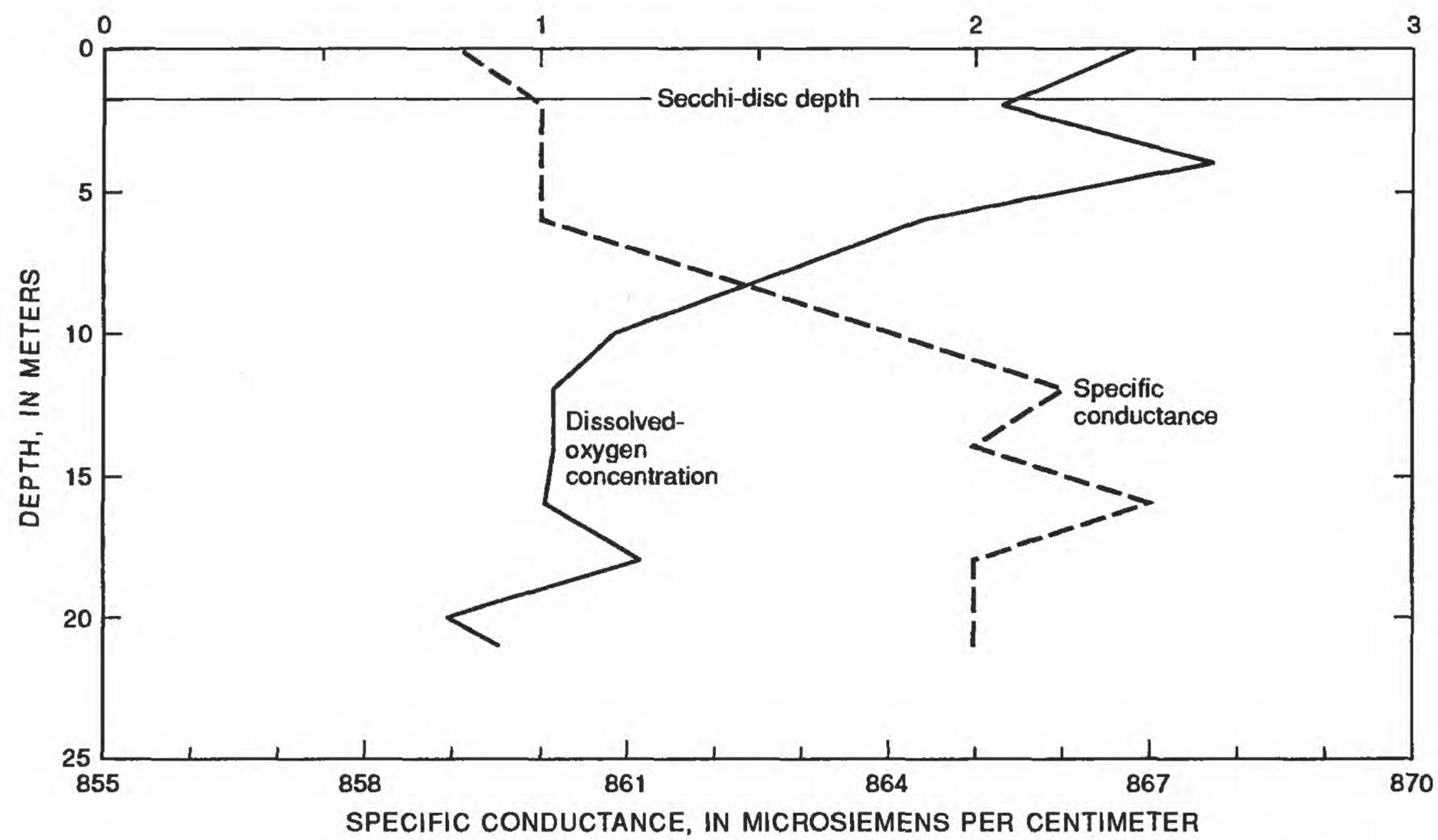

Figure 11. Relation of Secchi-disc depth to specific conductance and dissolved-oxygen concentration in the Tonto arm, Theodore Roosevelt Lake, Arizona, December 1991.

Table 5. Statistical summary of nutrient data for Theodore Roosevelt Lake, Arizona, from the limnological reconnaissance, 1990-92

\begin{tabular}{|c|c|c|c|c|c|c|c|}
\hline Location & Number & $\begin{array}{l}\text { Less than } \\
\text { (percent) }\end{array}$ & Medlan & Mean & $\begin{array}{l}\text { Standard } \\
\text { deviation }\end{array}$ & Minimum & Maximum \\
\hline \multicolumn{8}{|c|}{$\begin{array}{l}\text { Secchi-dise depth, in meters } \\
\text { ( }>3.7 \mathrm{~m} \text {, oligotrophic; } 2.0-3.7 \mathrm{~m} \text {, mesotrophic; }<2.0 \mathrm{~m} \text {, eutrophic) }\end{array}$} \\
\hline Salt bay ................ & 6 & 0 & 1.7 & 1.7 & 0.3 & 1.2 & 2.0 \\
\hline Tonto arm ............. & 6 & 0 & 1.8 & 1.9 & .7 & 1.1 & 3.0 \\
\hline Forebay ..................... & 4 & 0 & 2.2 & 2.2 & .5 & 1.7 & 2.7 \\
\hline \multicolumn{8}{|c|}{$\begin{array}{l}\text { Chlorophyll-a concentrations, in micrograms per liter } \\
\text { (<7 } \mathrm{g} / \mathrm{L} \text {, oligotrophic; } 7-12 \mu \mathrm{g} / \mathrm{L} \text {, mesotrophic; >12 } \mu \mathrm{g} / \mathrm{L} \text {, eutrophic) }\end{array}$} \\
\hline Salt bay ................ & 6 & 0 & 2.1 & 3.8 & 5.1 & .80 & 14 \\
\hline Tonto arm ............. & 6 & 0 & 1.5 & 2.4 & 2.1 & .70 & 6.5 \\
\hline 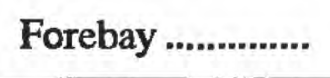 & 5 & 0 & 1.5 & 2.2 & 1.3 & 1.3 & 4.3 \\
\hline \multicolumn{8}{|c|}{$\begin{array}{l}\text { Total phosphorus as } \mathrm{P} \text {, in milligrams per gram } \\
\text { ( }<0.010 \mathrm{mg} / \mathrm{L} \text {, oligotrophic; } 0.010-0.020 \mathrm{mg} / \mathrm{L} \text {, mesotrophic; }>0.020 \mathrm{mg} / \mathrm{L} \text {, eutrophic) }\end{array}$} \\
\hline 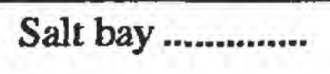 & 16 & 25 & .02 & .03 & .02 & .01 & .10 \\
\hline Tonto arm .............. & 17 & 24 & .02 & .02 & .01 & .01 & .05 \\
\hline Forebay ................ & 15 & 33 & .03 & .04 & .03 & .01 & .13 \\
\hline
\end{tabular}

${ }^{1}$ U.S. Environmental Protection Agency (1974).

${ }^{2}$ Arizona Game and Fish Department (1982-83). 
Because different laboratory techniques were used for determining chlorophyll- $a$ concentrations, the 1975 data cannot be compared with data from this study (Paul Soliven, U.S. Geological Survey, 1994). For this study, the greatest mean value $(4.3 \mu \mathrm{g} / \mathrm{L})$ was in December 1991; the least mean value $(0.9 \mu \mathrm{g} / \mathrm{L})$ was in August 1991. Areally, the Salt bay had the greatest mean value $(3.8 \mu \mathrm{g} / \mathrm{L})$, the Tonto arm had a mean value of $2.4 \mu \mathrm{g} / \mathrm{L}$, and the forebay had the least mean value $(2.2 \mu \mathrm{g} / \mathrm{L})$. Chlorophyll- $a$ concentrations were consistently greater adjacent to inflows than in the center of the lake during the Rinne (1973) study and during this study.

The Secchi-disc depth ranged from 1.1 to $3.0 \mathrm{~m}$, and the mean depth was $1.9 \mathrm{~m}$. This depth lies within the range of values indicating eutrophy (U.S. Environmental Protection Agency, 1974). Areally, the greatest mean Secchi-disc depth was $2.2 \mathrm{~m}$ at the forebay, an area less affected by runoff than the other two sites on the arms of the lake. The least mean depth was $1.7 \mathrm{~m}$ on the Salt bay, an area affected by runoff. The greatest mean Secchi-disc depth $(2.6 \mathrm{~m})$ occurred during stratified conditions in August 1991; the least mean depth $(1.1 \mathrm{~m})$ occurred in April 1991 after large inflows from March storms.

Phosphorus availability generally is thought to be the critical factor in eutrophication of lakes. For this study, concentrations of total phosphorus for Roosevelt Lake were within the range considered eutrophic (Arizona Game and Fish Department, 1982-83). Concentrations of total phosphorus ranged from 0.01 to $0.13 \mathrm{mg} / \mathrm{L}$, and the mean concentration was $0.03 \mathrm{mg} / \mathrm{L}$. Areally, the greatest mean concentration of total phosphorus $(0.04 \mathrm{mg} / \mathrm{L})$ was at the forebay; the least mean concentration $(0.02 \mathrm{mg} / \mathrm{L})$ was on the Tonto arm. Seasonally, little difference occurred in the mean concentrations $(0.02$ to $0.04 \mathrm{mg} / \mathrm{L})$. The mean concentrations of total phosphorus were similar in 1975 and 1992 and both data sets indicated that the forebay had a greater concentration of phosphorus than the arms of the lake. Within the water column, the greatest mean concentration of total phosphorus $(0.05 \mathrm{mg} / \mathrm{L})$ was in the hypolimnion; the least mean value $(0.02 \mathrm{mg} / \mathrm{L})$ was in the epilimnion.

\section{Major lons}

Chemically, the water sampled from the lake sites was more similar to the water from the Salt River rather than to the water from Tonto Creek (fig. 12). Tonto Creek differed chemically from the Salt River, Roosevelt Lake, and Roosevelt Dam outflow. Calcium and bicarbonate were predominant in water from Tonto Creek and sodium and chloride were predominant in water from the Salt River and Roosevelt Lake. This chemical difference also was indicated by the SRP data.

Concentrations of major ions were greatest in September 1990 and were least in April 1991 and March and May 1992. The sampling in September 1990 was preceded by several weeks without precipitation and the April 1991 and March and May 1992 sampling was preceded by several weeks during which precipitation may have produced sufficient runoff to cause dilution. Seasonal variations were evident in the chemical data from all of the lake sites but were most pronounced in data from the metalimnetic water of the Salt bay (fig. 13).

\section{Dlssolved Metals}

Summary statistics for arsenic, barium, copper, iron, manganese, nickel, strontium, and zinc were determined using estimates from robust log-probability regressions (Helsel and Cohn, 1988; table 6 , this report). Concentrations of cadmium, lead, and selenium were less than their respective analytical detection limits.

Concentrations of dissolved arsenic, iron, manganese, nickel, and strontium were less in lake water than in streams (table 6). The median concentration of dissolved manganese at the lake sites $(0.46 \mu \mathrm{g} / \mathrm{L})$ was considerably less than the median concentration in the streams $(22 \mu \mathrm{g} / \mathrm{L})$. The mean concentration of dissolved barium was the same at the lake and streams sites $(61 \mu \mathrm{g} / \mathrm{L})$. Concentrations of dissolved copper and zinc were greater in the lake than in the streams.

The mean and median values for each constituent varied significantly, primarily due to the number of censored data and the varied detection limits. The median concentration of dissolved manganese at the lake sites $(0.46 \mu \mathrm{g} / \mathrm{L})$ was less 

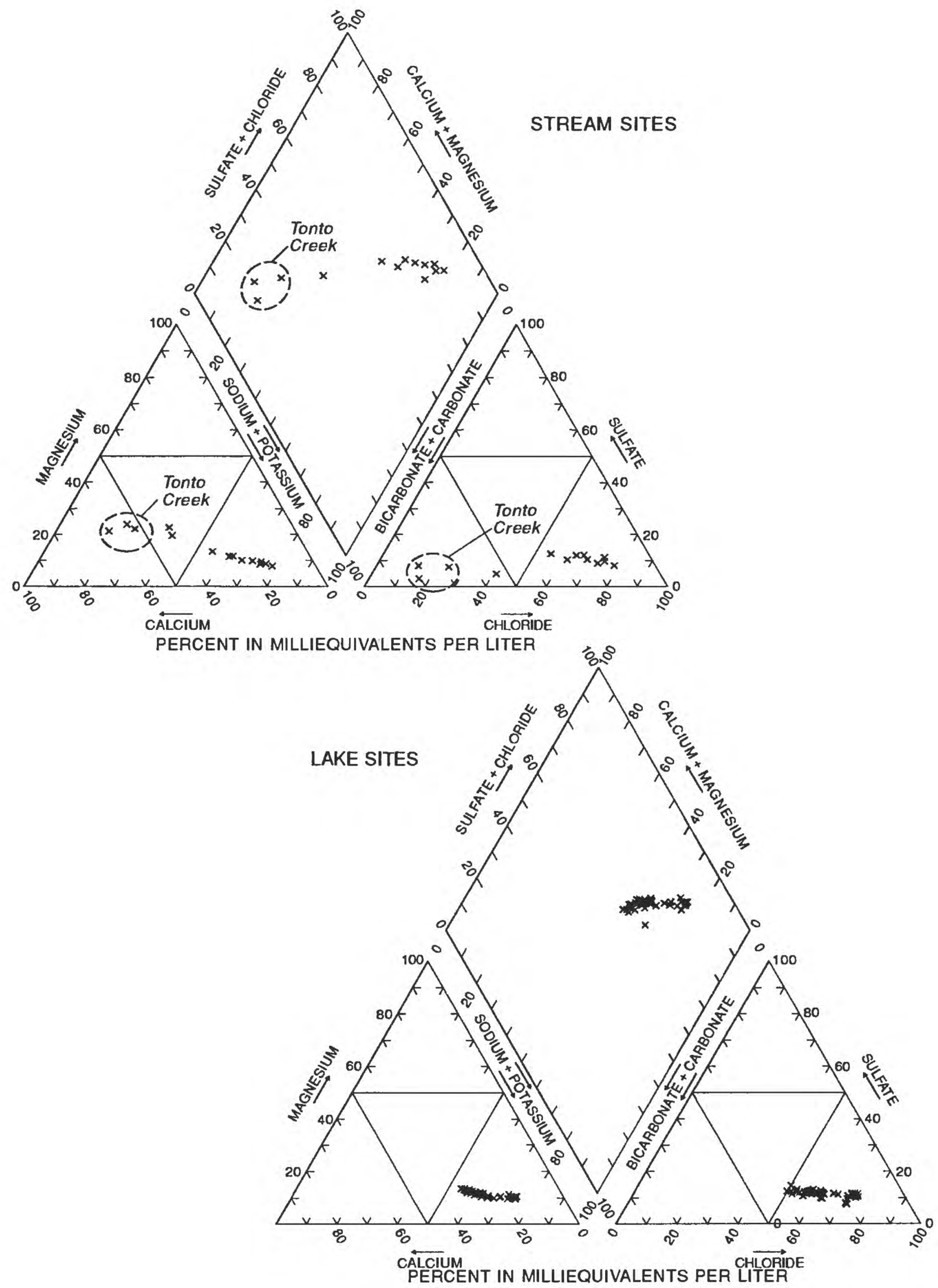

Flgure 12. Compositions of water from Tonto Creek, Salt River, and Theodore Roosevelt Lake, Arizona, September 1990 through May 1992. 


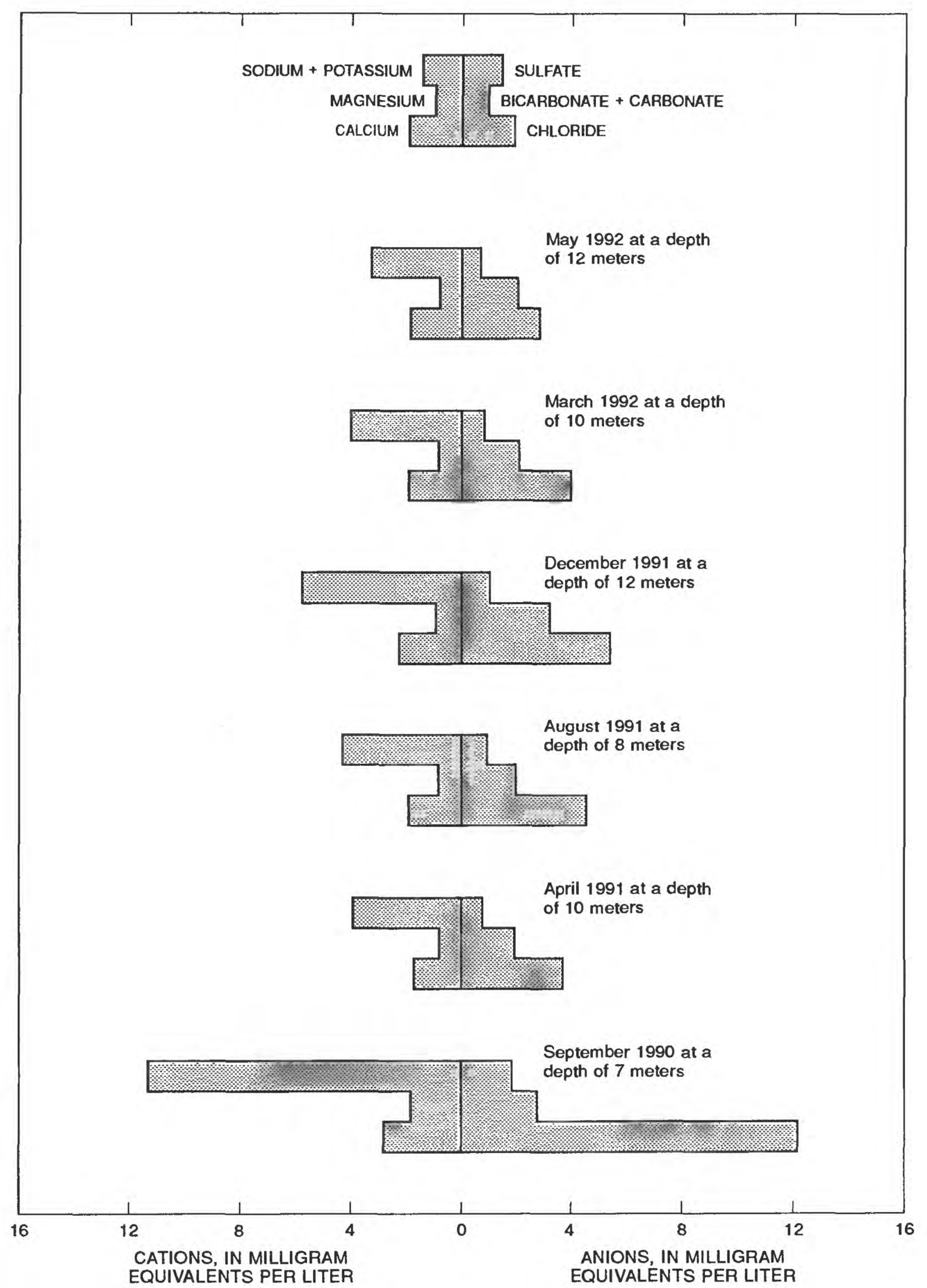

Figure 13. Seasonal variations in the metalimnion in the Salt bay, Theodore Roosevelt Lake, Arizona, September 1990 through May 1992. 
Table 6. Statistical summary of selected dissolved-metal concentrations in water samples from the limnological reconnaissance of Theodore Roosevelt Lake, Arizona, 1990-92

[ $\mu \mathrm{g} / \mathrm{L}$, micrograms per liter; ---, dashes indicate value not determined; ND, not detected]

\begin{tabular}{|c|c|c|c|c|c|c|c|c|}
\hline Site & $\begin{array}{c}\text { Arsenlc } \\
(\mu g / L)\end{array}$ & $\begin{array}{l}\text { Barlum } \\
(\mu g / L)\end{array}$ & $\begin{array}{c}\text { Copper } \\
(\mu g / L)\end{array}$ & $\begin{array}{l}\text { Iron } \\
(\mu g / L)\end{array}$ & $\begin{array}{l}\text { Man- } \\
\text { ganese } \\
(\mu g / L)\end{array}$ & $\begin{array}{l}\text { Nlckel } \\
(\mu g / L)\end{array}$ & $\begin{array}{l}\text { Strontlum } \\
(\mu g / L)\end{array}$ & $\begin{array}{c}\text { Zlno } \\
(\mu g / L)\end{array}$ \\
\hline \multicolumn{9}{|l|}{ Salt bay } \\
\hline 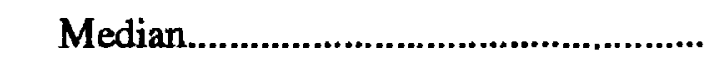 & 2.0 & 46 & 2.1 & 4.0 & 0.3 & 0.68 & 300 & 3.0 \\
\hline 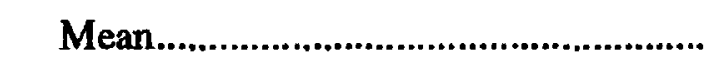 & 2.3 & 57 & 4.0 & 8.3 & 46 & 1.7 & 330 & 3.4 \\
\hline 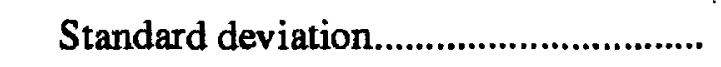 & .7 & 26 & 4.8 & 16 & 129 & 3.3 & 91 & 2.6 \\
\hline Number of samples ............................... & 16 & 16 & 16 & 16 & 16 & 16 & 16 & 16 \\
\hline $\begin{array}{l}\text { Percent of samples with concentration } \\
\text { below detection limit........................ }\end{array}$ & 31 & 0 & 62 & 38 & 75 & 62 & 12 & 50 \\
\hline \multicolumn{9}{|l|}{ Tonto arm } \\
\hline 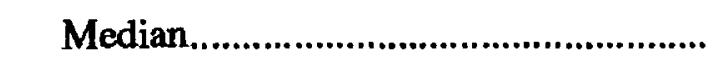 & 3.0 & 53 & .59 & 3.0 & $-\cdots+\cdots$ & ----..-- & 293 & 1.6 \\
\hline 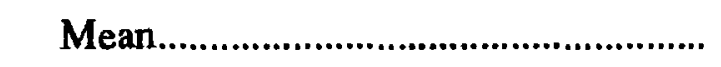 & 2.7 & 63 & 2.6 & 4.2 & ------ & $-\ldots . .-$ & 306 & 2.9 \\
\hline 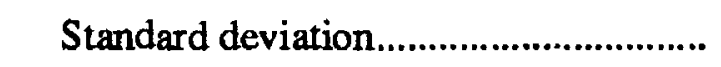 & .4 & 25 & 4.6 & 5.3 & -..---- & -...-- & 42 & 3.2 \\
\hline 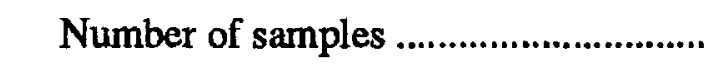 & 17 & 17 & 17 & 17 & 17 & 17 & 17 & 17 \\
\hline $\begin{array}{l}\text { Percent of samples with concentration } \\
\text { below detection limit............................ }\end{array}$ & 41 & 0 & 76 & 53 & 88 & 82 & 42 & 71 \\
\hline \multicolumn{9}{|l|}{ Forebay } \\
\hline Median & 2.2 & 53 & 1.2 & 5.0 & .21 & -..--- & 290 & 3.5 \\
\hline Mean & 2.8 & 62 & 2.1 & 20 & 114 & ------- & 317 & 3.9 \\
\hline Standard deviation $\ldots . . . . . . . . . . . . . . . . . . . . . . . . . . .$. & 1.2 & 26 & 3.4 & 42 & 299 & ------ & 92 & 2.3 \\
\hline 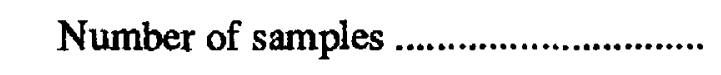 & 15 & 14 & 15 & 14 & 15 & 15 & 15 & 14 \\
\hline $\begin{array}{l}\text { Percent of samples with concentration } \\
\text { below detection limit.......................... }\end{array}$ & 33 & 0 & 73 & 43 & 73 & 80 & 13 & 50 \\
\hline \multicolumn{9}{|l|}{ All lake sites } \\
\hline 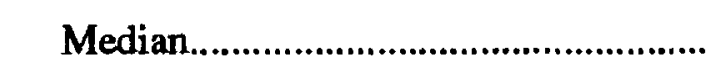 & 2.4 & 52 & 1.5 & 4.0 & .46 & .30 & 295 & 3.0 \\
\hline Mean & 2.6 & 61 & 3.1 & 11 & 54 & 1.3 & 318 & 3.6 \\
\hline 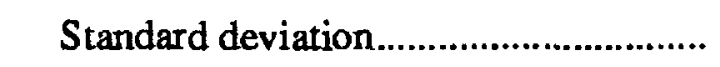 & .87 & 25 & 4.3 & 25 & 185 & 2.7 & 78 & 2.7 \\
\hline Number of samples ............................... & 48 & 47 & 48 & 47 & 48 & 48 & 48 & 47 \\
\hline $\begin{array}{l}\text { Percent of samples with concentration } \\
\text { below detection limit........................ }\end{array}$ & 35 & 0 & 71 & 45 & 79 & 75 & 17 & 57 \\
\hline
\end{tabular}


Table 6. Statistical summary of selected dissolved-metal concentrations in water samples from the limnological reconnaissance of Theodore Roosevelt Lake, Arizona, 1990-92-Continued

\begin{tabular}{|c|c|c|c|c|c|c|c|c|}
\hline Site & $\begin{array}{c}\text { Arsenic } \\
(\mu g / L)\end{array}$ & $\begin{array}{l}\text { Barium } \\
(\mu g / L)\end{array}$ & $\begin{array}{l}\text { Copper } \\
(\mu g / L)\end{array}$ & $\begin{array}{c}\text { Iron } \\
(\mu g / L)\end{array}$ & $\begin{array}{c}\text { Man- } \\
\text { ganese } \\
(\mu g / L)\end{array}$ & $\begin{array}{l}\text { Nickel } \\
(\mu \mathrm{g} / \mathrm{L})\end{array}$ & $\begin{array}{l}\text { Strontlum } \\
(\mu g / L)\end{array}$ & $\begin{array}{l}\operatorname{Zinc} \\
(\mu g / L)\end{array}$ \\
\hline \multicolumn{9}{|l|}{ Salt River } \\
\hline 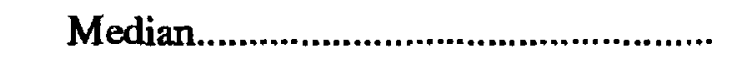 & 4.0 & 25 & 1.0 & 18 & 370 & 2.0 & 637 & ND \\
\hline 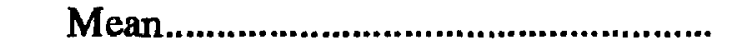 & 4.2 & 38 & 1.4 & 17 & 376 & 2.2 & 564 & ND \\
\hline 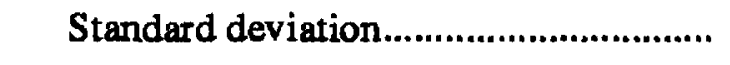 & 2.9 & 35 & .5 & 1.8 & 244 & 1.1 & 295 & ND \\
\hline Number of samples ..................................... & 5 & 5 & 5 & 5 & 5 & 5 & 4 & 5 \\
\hline $\begin{array}{l}\text { Percent of samples with concentration } \\
\text { below detection limit......................... }\end{array}$ & 0 & 40 & $\mathbf{0}$ & 40 & 0 & 20 & 25 & 100 \\
\hline \multicolumn{9}{|l|}{ Tonto Creek } \\
\hline 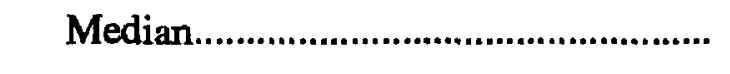 & 2.0 & 68 & -.---- & ---- & 7.1 & ND & 190 & $\ldots$ \\
\hline Mean & 2.2 & 79 & ----- & ---- & 8.8 & ND & 194 & ------ \\
\hline 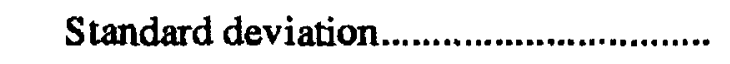 & 1.1 & 26 & ---- & --- & 7.5 & ND & 43 & -a---- \\
\hline Number of samples ...................................... & 5 & 5 & 5 & 5 & 5 & 5 & 5 & 5 \\
\hline $\begin{array}{l}\text { Percent of samples with concentration } \\
\text { below detection limit............................. }\end{array}$ & 40 & 20 & 60 & 80 & 40 & 100 & 20 & 80 \\
\hline \multicolumn{9}{|l|}{ Roosevelt Dam outfiow } \\
\hline 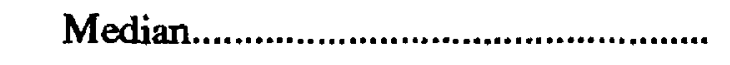 & 3.3 & 61 & ------ & 9.0 & 12 & 2.0 & 330 & 3.3 \\
\hline 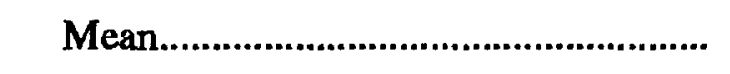 & 3.5 & 61 & -.---- & 54 & 320 & 3.2 & 362 & 3.3 \\
\hline 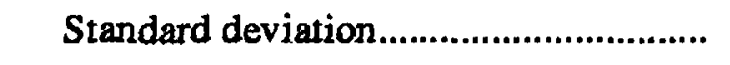 & 1.5 & 10 & $\cdots-$ & 98 & 429 & 3.8 & 62 & .67 \\
\hline Number of samples & 5 & 5 & 5 & 5 & 5 & 5 & 5 & 5 \\
\hline 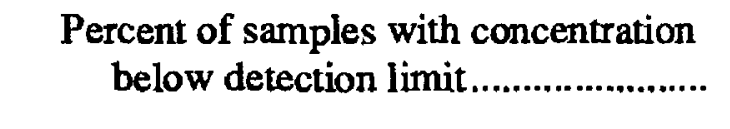 & 40 & 20 & 60 & 20 & 20 & 20 & 20 & 40 \\
\hline \multicolumn{9}{|l|}{ All stream sites } \\
\hline 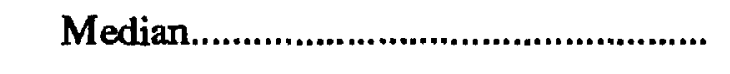 & 3.0 & 56 & 1.5 & 7.0 & 22 & 1.1 & 314 & 2.6 \\
\hline Mean & 3.4 & 61 & 1.6 & 23 & 236 & 2.0 & 356 & 2.9 \\
\hline 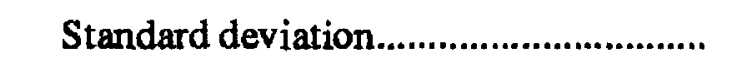 & 2.0 & 28 & .72 & 58 & 311 & 2.4 & 213 & 1.0 \\
\hline 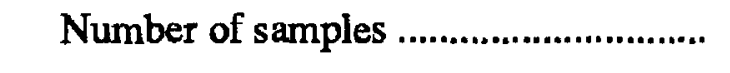 & 15 & 15 & 15 & 15 & 15 & 15 & 14 & 15 \\
\hline $\begin{array}{l}\text { Percent of samples with concentration } \\
\text { below detection limit............................ }\end{array}$ & 27 & 27 & 40 & 47 & 20 & 47 & 21 & 73 \\
\hline
\end{tabular}


than the mean value $(54 \mu \mathrm{g} / \mathrm{L})$. The median concentration of manganese at the stream sites $(22 \mu \mathrm{g} / \mathrm{L})$ also was less than the mean value $(236 \mu \mathrm{g} / \mathrm{L})$.

The mean and median concentrations of dissolved arsenic, manganese, and strontium were greater for the Salt River than for Tonto Creek. The mean concentration of dissolved strontium for the Salt River $(564 \mu \mathrm{g} / \mathrm{L})$ was almost three times greater than that for Tonto Creek $(194 \mu \mathrm{g} / \mathrm{L})$. The median concentration of dissolved iron for the Salt River $(18 \mu \mathrm{g} / \mathrm{L})$ was greater than the median for the Roosevelt Dam outflow $(9.0 \mu \mathrm{g} / \mathrm{L})$; however, the mean concentration for the outflow $(54 \mu \mathrm{g} / \mathrm{L})$ was greater than the mean for the Salt River $(17 \mu \mathrm{g} / \mathrm{L})$. The median concentrations of dissolved nickel were the same for the Salt River and the dam outflow $(2.0 \mu \mathrm{g} / \mathrm{L})$.

Of the lake sites, the forebay had the greatest mean concentrations of dissolved arsenic, iron, manganese, and zinc. The mean concentration of dissolved iron for the forebay was $20 \mu \mathrm{g} / \mathrm{L}$ compared with $8.3 \mu \mathrm{g} / \mathrm{L}$ and $4.2 \mu \mathrm{g} / \mathrm{L}$ for the Salt bay and Tonto arm, respectively. The mean concentration of dissolved manganese for the forebay $(114 \mu \mathrm{g} / \mathrm{L})$ was more than two times that of the Salt bay $(46 \mu \mathrm{g} / \mathrm{L})$. This increase in concentration may be due to the greater thickness of the hypolimnion at the forebay, resulting in a larger reducing zone where metals desorb from sediments. The mean concentrations of dissolved copper and strontium were greatest for the Salt bay. The mean concentration of dissolved barium was greatest for the Tonto arm.

\section{Water-Quallty Standards}

Several samples from Roosevelt Lake exceeded ADEQ (Arizona Department of Environmental Quality, 1992c) water-quality standards for arsenic and beryllium and USEPA (U.S. Environmental Protection Agency, 1992) secondary maximum contaminant levels (SMCL's) in drinking water for chloride and dissolved solids (table 7). Several water samples from the two major tributaries, the Salt River and Tonto Creek, exceeded the ADEQ standard for arsenic. In addition, some of the Salt River samples exceeded the ADEQ standards for beryllium and turbidity and exceeded the USEPA
SMCL for dissolved solids. Additional data for Pinal Creek, a tributary of the Salt River, are provided to illustrate a potential source of metals and dissolved solids to the Salt River upstream from Roosevelt Lake, although samples were not collected for this study. Several samples from the streamflow-gaging station, Pinal Creek at Setka Ranch near Globe (09848380), collected from September 1990 to May 1992, exceeded or were outside the range of ADEQ water-quality standards for beryllium, manganese, nickel, dissolved oxygen, and $\mathrm{pH}$, and exceeded the USEPA SMCL for dissolved solids.

Arsenic concentrations exceeded standards in 3 of 48 samples collected from the three lake sites. The three dissolved-arsenic concentrations that exceeded standards ranged from 4 to $6 \mu \mathrm{g} / \mathrm{L}$. The sample concentrations exceeded the total-arsenic standard of $3.1 \mu \mathrm{g} / \mathrm{L}$ for fish consumption but did not exceed standards for domestic-water source $(50 \mu \mathrm{g} / \mathrm{L})$ or other protected uses. Arsenic concentrations in Roosevelt Lake generally were within the water-quality standards.

Beryllium concentrations are known to have exceeded standards in 5 of 44 samples analyzed at the three lake sites. Only five dissolved-beryllium concentrations were detected at or above the laboratory detection limit of $0.5 \mu \mathrm{g} / \mathrm{L}$, which is above the water-quality standards. Beryllium values in Roosevelt Lake ranged from less than 0.5 to $0.7 \mu \mathrm{g} / \mathrm{L}$. The standards for protected uses that were exceeded included the standard of $0.008 \mu \mathrm{g} / \mathrm{L}$ for domestic-water source, the standard of $0.21 \mu \mathrm{g} / \mathrm{L}$. for fish consumption, and the standard of $0.33 \mu \mathrm{g} / \mathrm{L}$ for full-body contact. Because the laboratory detection limit was greater than the standards, all detected values exceeded standards. The beryllium analyses could not be adequately applied to the standards because some of the samples may have contained concentrations that were below the analytical-detection limit but above the standard. Further investigation is needed to determine what proportion of these metals is due to human activity rather than from naturally occurring conditions.

The USEPA SMCL for chloride was exceeded in 8 of 48 samples collected at the three lake sites. Chloride concentrations ranged from 90 to $450 \mathrm{mg} / \mathrm{L}$, and the mean value was $230 \mathrm{mg} / \mathrm{L}$, which is below the USEPA SMCL for chloride (250 mg/L). 
Table 7. Analyses from the limnological reconnaissance and Pinal Creok at Setka Ranch, Arizona, 1990-92, that exceeded or were outside the range of water-quality standards

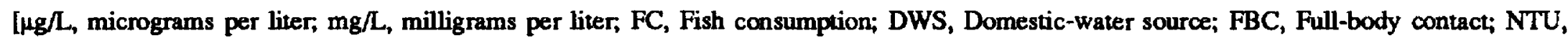
nephelometric turbidity units; A\&Ww, Aquatic and wildlife, warm-water fishery; AgI, Agricultural irrigation; A\&W, Aquatic and wildlife]

\begin{tabular}{|c|c|c|c|c|c|c|}
\hline Site & Constltuent & $\begin{array}{c}\text { Water } \\
\text { use }\end{array}$ & $\begin{array}{c}\text { Wster-quaility } \\
\text { atandard }\end{array}$ & $\begin{array}{c}\text { Maximum } \\
\text { messured } \\
\text { value }\end{array}$ & $\begin{array}{l}\text { Percent of } \\
\text { semples } \\
\text { exceedling or } \\
\text { outside range } \\
\text { of standard }\end{array}$ & $\begin{array}{c}\text { Number of } \\
\text { sampie } \\
\text { anglyses }\end{array}$ \\
\hline \multirow{8}{*}{ Roosevelt Lake } & \multicolumn{6}{|c|}{ Arizona Department of Environmental Quality water-quality standards } \\
\hline & Arsenic, total, $\mu \mathrm{g} / \mathrm{L}$ & FC & 3.1 & (1) 6 & 6 & 48 \\
\hline & Beryllium, total, $\mu \mathrm{g} / \mathrm{L}$ & DWS & .008 & .7 & 11 & 44 \\
\hline & Beryllium, total, $\mu \mathrm{g} / \mathrm{L}$ & FC & .21 & .7 & 11 & 44 \\
\hline & Beryllium, total, $\mu \mathrm{g} / \mathrm{L}$ & FBC & .33 & .7 & 11 & 44 \\
\hline & \multicolumn{6}{|c|}{ U.S. Environmental Protection Agency secondary maximum contaminant levels for drinking water } \\
\hline & Chloride, dissolved, $\mathrm{mg} / \mathrm{L}$ & & 250 & 450 & 17 & 48 \\
\hline & Dissolved solids, $\mathrm{mg} / \mathrm{L}$ & & 500 & 1,100 & 33 & 48 \\
\hline \multirow{6}{*}{ Salt River } & \multicolumn{6}{|c|}{ Arizona Department of Environmental Quality water-quality standards } \\
\hline & Arsenic, total, $\mu \mathrm{g} / \mathrm{L}$ & FC & 3.1 & 7 & 60 & 5 \\
\hline & Beryllium, total, $\mu \mathrm{g} / \mathrm{L}$ & FC & .21 & (1).6 & 25 & 4 \\
\hline & Turbidity, NTU & $A \& W w$ & 50 & 170 & 40 & 5 \\
\hline & \multicolumn{6}{|c|}{ U.S. Environmental Protection Agency secondary maximum contaminant level for drinking water } \\
\hline & Dissolved solids, $\mathrm{mg} / \mathrm{L}$ & & 500 & 1,470 & 60 & 5 \\
\hline \multirow{2}{*}{ Tonto Creek } & \multicolumn{6}{|c|}{ Arizona Department of Environmental Quality water-quality standard } \\
\hline & Arsenic, total, $\mu \mathrm{g} / \mathrm{L}$ & FC & 3.1 & 4 & 20 & 5 \\
\hline \multirow{9}{*}{$\begin{array}{r}\text { Pinal Creek at } \\
\text { Setka Ranch }\end{array}$} & \multicolumn{6}{|c|}{ Arizona Department of Environmental Quality water-quality standards } \\
\hline & Beryllium, total, $\mu \mathrm{g} / \mathrm{L}$ & FC & .21 & (1) 2 & 27 & 11 \\
\hline & Manganese, total, $\mathrm{mg} / \mathrm{L}$ & AgI & 10.0 & 100 & 100 & 11 \\
\hline & Nickel, total, $\mathrm{mg} / \mathrm{L}$ & FC & .4 & 1.1 & 100 & 10 \\
\hline & Dissolved oxygen, $\mathrm{mg} / \mathrm{L}$ & $A \& W w$ & $\geq 6.0$ & 7.0 & 45 & 11 \\
\hline & $\mathrm{pH}$, standard units & FBC & $\begin{array}{l}\text { minimum } 6.5 \\
\text { maximum } 9.0\end{array}$ & 6.6 & 73 & 11 \\
\hline & $\mathrm{pH}$, standard units & A\&Ww & $\begin{array}{l}\text { minimum } 6.5 \\
\text { maximum } 9.0\end{array}$ & 6.6 & 73 & 11 \\
\hline & \multicolumn{6}{|c|}{ U.S. Environmental Protection Agency secondary maximum contaminant level for drinking water } \\
\hline & Dissolved solids, $\mathrm{mg} / \mathrm{L}$ & & 500 & 5,640 & 100 & 11 \\
\hline
\end{tabular}

\footnotetext{
${ }^{1}$ Dissolved-constituent concentration.
} 
The USEPA SMCL for dissolved-solids concentration in drinking water was exceeded in 16 of 48 samples collected at the three lake sites. Dissolved solids ranged from 285 to $1,100 \mathrm{mg} / \mathrm{L}$, and had a mean value of $557 \mathrm{mg} / \mathrm{L}$, which exceeded the USEPA SMCL for dissolved solids $(500 \mathrm{mg} / \mathrm{L})$.

\section{Bottom-SedIment Metals}

Although 43 percent of the analyses of bottom sediment for specific metals had values less than the detection limits, mean values were calculated for selected metals from estimates using robust log-probability regressions (Helsel and Cohn, 1988; table 8, this report). Concentrations of cadmium, lead, mercury, selenium, and silver in bottom sediment from the stream sites were less than the detection limits. Concentrations of lead, mercury, and selenium in bottom sediment from the lake sites were less than the detection limits. Summary statistics were not calculated for iron or manganese because several samples contained concentrations of these constituents that exceeded the maximum reporting level for the laboratory analytical method. Measured concentrations of iron ranged from 51 to more than $13,000 \mu \mathrm{g} / \mathrm{g}$ and measured concentrations of manganese ranged from 14 to more than $1,800 \mu \mathrm{g} / \mathrm{g}$. Measured concentrations of arsenic ranged from 2 to $7 \mu \mathrm{g} / \mathrm{g}$ and concentrations were less than the detection limit in 22 of the 27 samples. Barium concentrations were measured in one sample from each site and ranged from $28 \mu \mathrm{g} / \mathrm{g}$ at Tonto Creek to $80 \mu \mathrm{g} / \mathrm{g}$ at the Salt arm.

The mean concentrations of chromium, copper, and zinc in bottom sediment were greater for stream sites than for lake sites. The mean concentration of chromium was slightly greater for bottom sediment from the stream sites $(16 \mu \mathrm{g} / \mathrm{g})$ than for bottom sediment from the lake sites $(13 \mu \mathrm{g} / \mathrm{g})$. The mean concentration of copper for the stream sites $(163 \mu \mathrm{g} / \mathrm{g})$ was considerably greater than the median for the lake sites $(33 \mu \mathrm{g} / \mathrm{g})$; however, the median concentration of copper for the stream sites $(5.5 \mu \mathrm{g} / \mathrm{g})$ was less than the median for the lake sites $(20 \mu \mathrm{g} / \mathrm{g})$.

Within the lake, bottom sediment from the Tonto arm had the greatest mean concentrations of chromium, copper, nickel, and zinc. Bottom sediment from the forebay had the greatest median concentrations of chromium and nickel. Bottom sediment from the Tonto arm and the forebay had the greatest median concentrations of zinc. Bottom sediment from the Salt bay had the greatest median concentration of copper.

The mean concentrations of metals in bottom sediment from the Salt River were greater than those in bottom sediment from Tonto Creek. The mean concentration of zinc was two times greater for the Salt River $(48 \mu \mathrm{g} / \mathrm{g})$ than for Tonto Creek $(22 \mu \mathrm{g} / \mathrm{g})$. The maximum concentration of nickel for the Salt River $(20 \mu \mathrm{g} / \mathrm{g})$ was twice that for Tonto Creek $(10 \mu \mathrm{g} / \mathrm{g})$.

Concentrations of metals in bottom sediment from the stream sites varied seasonally during the study. At the Salt River site, the greatest concentrations of copper, manganese, and zinc were found in samples collected in August 1991. The copper concentration was $1,200 \mu \mathrm{g} / \mathrm{g}$ in August 1991; the second greatest concentration $(80 \mu \mathrm{g} / \mathrm{g})$ was in December 1991. The greatest manganese concentration for Tonto Creek $(180 \mu \mathrm{g} / \mathrm{g})$ occurred in May 1992.

Samples collected during the ADEQ study in 1989 yielded greater metal concentrations than the mean values from this study except for copper on the Tonto arm. The nickel concentration in 1989 for the forebay $(55.7 \mu \mathrm{g} / \mathrm{g})$ was three times greater than the mean concentration for $1992(17 \mu \mathrm{g} / \mathrm{g})$. The copper concentrations in 1989 for the forebay and Salt inflow were 84.5 and $87.5 \mu \mathrm{g} / \mathrm{g}$, respectively; the mean copper concentrations in 1992 for the forebay and Salt inflow were 23 and $20 \mu \mathrm{g} / \mathrm{g}$, respectively. The copper concentration in the bottom sediment from the Tonto arm was $39.5 \mu \mathrm{g} / \mathrm{g}$ in 1989 compared with the mean value of $68 \mu \mathrm{g} / \mathrm{g}$ for 1992.

\section{SUMMARY AND CONCLUSIONS}

The water quality of Roosevelt Lake, a reservoir on the Salt River and Tonto Creek, potentially could be affected by contamination from the Pinal Creek drainage basin and other upstream areas. Ground water in parts of the Pinal Creek basin contains elevated concentrations of manganese, copper, and other metals and contributes to the flow of Pinal Creek, which is a tributary of the Salt River. 
Table 8. Statistical summary of selected metal concentrations in bottom-sediment samples from the limnological reconnaissance of Theodore Roosevelt Lake, Arizona, 1990-92

[ $\mu \mathrm{g} / \mathrm{g}$, micrograms per liter, ND, not detected]

\begin{tabular}{|c|c|c|c|c|}
\hline Site & $\begin{array}{c}\text { Chromium } \\
(\mu \mathrm{g} / \mathrm{g})\end{array}$ & $\begin{array}{l}\text { Copper } \\
(\mu g / g)\end{array}$ & $\begin{array}{l}\text { Nickel } \\
(\mu g / g)\end{array}$ & $\begin{array}{c}\text { Zinc } \\
(\mu g / g)\end{array}$ \\
\hline \multicolumn{5}{|l|}{ Salt inflow } \\
\hline Median & 9.5 & 20 & 8.5 & 15 \\
\hline Mean & 9.5 & 20 & 8.3 & 18 \\
\hline Standard deviation. & 3.7 & 8.1 & 1.8 & 9.6 \\
\hline Number of samples & 4 & 4 & 4 & 4 \\
\hline Percent of samples with concentration below detection limit........ & $\mathbf{0}$ & 0 & 0 & $\mathbf{0}$ \\
\hline \multicolumn{5}{|l|}{ Salt arm } \\
\hline Median & 5.5 & 17 & 6.5 & 12 \\
\hline Mean & 8.7 & 27 & 9.0 & 17 \\
\hline Standard deviation & 8.5 & 32 & 8.1 & 18 \\
\hline Number of samples & 4 & 4 & 4 & 4 \\
\hline Percent of samples with concentration below detection limit......... & 25 & 25 & 25 & 25 \\
\hline \multicolumn{5}{|l|}{ Salt bay } \\
\hline 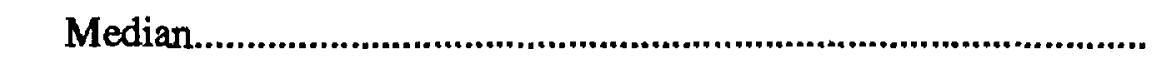 & 12 & 30 & 10 & 25 \\
\hline Mean & 13 & 26 & 12 & 21 \\
\hline 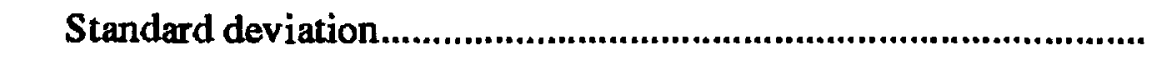 & 3.9 & 15 & 6.0 & 13 \\
\hline Number of samples & 4 & 4 & 4 & 4 \\
\hline Percent of samples with concentration below detection limit........ & 0 & 0 & 0 & 0 \\
\hline \multicolumn{5}{|l|}{ Tonto arm } \\
\hline 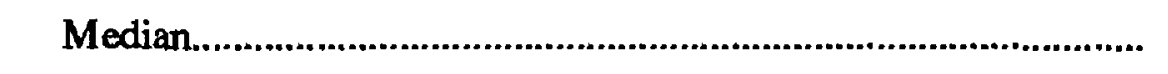 & 12 & 25 & 10 & 30 \\
\hline Mean & 19 & 68 & 18 & 30 \\
\hline Standard deviation & 15 & 95 & 15 & 8.2 \\
\hline Number of samples & 4 & 4 & 4 & 4 \\
\hline Percent of samples with concentration below detection limit........ & 0 & 0 & $\mathbf{0}$ & $\mathbf{0}$ \\
\hline \multicolumn{5}{|l|}{ Forebay } \\
\hline Median & 16 & 20 & 20 & 30 \\
\hline 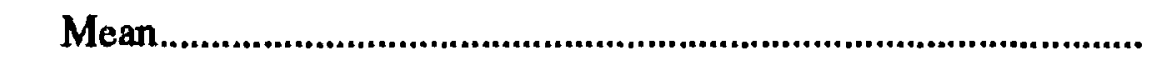 & 18 & 23 & 17 & 27 \\
\hline Standard deviation & 5.7 & 5.8 & 5.8 & 5.8 \\
\hline Number of samples & 3 & 3 & 3 & 3 \\
\hline Percent of samples with concentration below detection limit........ & 0 & $\mathbf{0}$ & $\mathbf{0}$ & 0 \\
\hline
\end{tabular}


Table 8. Statistical summary of selected metal concentrations in bottom-sediment samples from the limnological reconnaissance of Theodore Roosevelt Lake, Arizona, 1990-92-Continued

\begin{tabular}{|c|c|c|c|c|}
\hline Site & $\begin{array}{c}\text { Chromlum } \\
(\mu \mathrm{g} / \mathrm{g})\end{array}$ & $\begin{array}{c}\text { Copper } \\
(\mu \mathrm{g} / \mathrm{g})\end{array}$ & $\begin{array}{l}\text { Nickel } \\
(\mu g / g)\end{array}$ & $\begin{array}{c}\text { Zlnc } \\
(\mu g / g)\end{array}$ \\
\hline \multicolumn{5}{|l|}{ All lake sites } \\
\hline Median & 11 & 20 & 10 & 20 \\
\hline Mean & 13 & 33 & 12 & 22 \\
\hline Standard deviation & 8.6 & 45 & 8.6 & 12 \\
\hline Number of samples & 19 & 19 & 19 & 19 \\
\hline Percent of samples with concentration below detection limit....... & 5.3 & 5.3 & 5.3 & 5.3 \\
\hline \multicolumn{5}{|l|}{ Salt River } \\
\hline Median & 13 & 45 & 11 & 35 \\
\hline Mean & 16 & 325 & 13 & 48 \\
\hline Standard deviation & 12 & 584 & 5.0 & 38 \\
\hline Number of samples & 4 & 4 & 4 & 4 \\
\hline Percent of samples with concentration below detection limit ....... & 25 & 0 & 25 & 0 \\
\hline \multicolumn{5}{|l|}{ Tonto Creek } \\
\hline Median & 12 & ND & 8.5 & 20 \\
\hline Mean & 15 & ND & 8.5 & 22 \\
\hline Standard deviation & 9.2 & ND & 2.1 & 5.0 \\
\hline Number of samples & 4 & 4 & 4 & 4 \\
\hline Percent of samples with concentration below detection limit....... & 25 & 100 & 50 & 0 \\
\hline \multicolumn{5}{|l|}{ All stream sites } \\
\hline Median & 12 & 5.5 & 9.5 & 20 \\
\hline Mean & 16 & 163 & 10 & 35 \\
\hline Standard deviation & 10 & 420 & 4.1 & 28 \\
\hline Number of samples & 8 & 8 & 8 & 8 \\
\hline Percent of samples with concentration below detection limit ........ & 25 & 50 & 38 & 0 \\
\hline
\end{tabular}

The following significant results were observed from historical studies and the limnological reconnaissance:

ASU, 1970-71

- Roosevelt Lake is a warm, monomictic reservoir.
- Phosphate values ranged from 0.01 to $2.8 \mathrm{mg} / \mathrm{L}$, indicating eutrophy.

USEPA, 1975

- Roosevelt Lake is mesotrophic.

- Primary nutrient limitation by nitrogen occurred during sampling; however, the 
algal assay test indicated phosphorus limitation.

SRP study, 1980-90

- Major-ion concentrations indicate that Roosevelt Lake is chemically influenced more by the Salt River than by Tonto Creek.

- The semilog-regression analysis for discharges from the Salt River resulted in a moderate $r^{2}$ value of 0.79 for chloride and 0.73 for sodium. On the basis of stream inputs, discharge is not a good predictor of water chemistry leaving the dam.

ADEQ, 1989

- Contaminants detected in the three sediment samples included antimony, arsenic, beryllium, chromium, copper, lead, nickel, and zinc.

USGS limnological reconnaissance, 1990-92

- Roosevelt Lake begins thermal stratification in February and becomes strongly stratified by April. Temperature and specific-conductance data indicated that thermal tumover was completed by December, but the dissolved-oxygen data were more indicative of stratified conditions.

- Overall, Roosevelt Lake is considered to be mesotrophic. However, chlorophyll- $a$ concentrations ranged from 0.70 to $14 \mu \mathrm{g} / \mathrm{L}$, and the mean concentration was $2.8 \mu \mathrm{g} / \mathrm{L}$, indicating oligotrophy. The Secchi-disc depth ranged from 1.1 to $3.0 \mathrm{~m}$, and the mean depth was $1.9 \mathrm{~m}$, indicating eutrophy.

- Concentrations of dissolved arsenic, iron, manganese, nickel, and strontium were less in the lake than in the streams. The mean concentration of dissolved manganese was $54 \mu \mathrm{g} / \mathrm{L}$ for the lake sites and $236 \mu \mathrm{g} / \mathrm{L}$ for the stream sites. Mean concentrations of dissolved copper and zinc were greater for the lake sites than for the stream sites, whereas mean concentrations of barium were equal.

- Of the lake sites, the forebay had the greatest mean concentrations of dissolved arsenic, iron, manganese, and zinc. These greater concentrations may be due to the greater thickness of the hypolimnion at the forebay, resulting in a larger reducing zone where metals desorb from sediment.

- Several samples from Roosevelt Lake exceeded ADEQ water-quality standards for arsenic and beryllium concentrations and USEPA SMCL's for chloride and dissolved-solids concentrations.

- The mean concentrations of chromium, copper, and zinc were greater in bottom sediment from stream sites than from lake sites. The mean concentration of copper was $163 \mu \mathrm{g} / \mathrm{g}$ for bottom sediment from stream sites and $33 \mu \mathrm{g} / \mathrm{g}$ for bottom sediment from lake sites. The mean concentrations of chromium, copper, nickel, and zinc in bottom sediment from the Salt River were greater than concentrations of these constituents in bottom sediment from Tonto Creek.

- Of the three lake sites, sediment from the Tonto arm had the greatest mean concentrations of chromium, copper, nickel, and zinc.

Because much of the research on Roosevelt Lake has been done on surface samples rather than samples from varying depths, a thorough limnological evaluation of trends cannot be made using existing data. Bottom-sediment cores would provide data that could indicate the type and magnitude of historical environmental influences on Roosevelt Lake. The following approaches used in further study of Roosevelt Lake would provide information necessary for evaluating the limnological processes.

1. Continue to develop a baseline data set by which quantitative limnological interpretations can be made.

2. Evaluate the effects of increased lake elevation on limnological processes. 
3. Evaluate effects of metals loading from Pinal Creek on Roosevelt Lake.

4. Continue to study reducing conditions in the hypolimnion as they affect the dynamics and recirculation of metals from bottom sediment back into the water column.

\section{SELECTED REFERENCES}

Arizona Department of Environmental Quality, 1990, 1989 Air quality control for Arizona: Arizona Department of Environmental Quality, Phoenix, Arizona, $74 \mathrm{p}$. 1991, Report on the Arizona Priority Pollutant Program-1989: Arizona Department of Environmental Quality, Office of Water Quality, Phoenix, Arizona.

1992a, Arizona water quality assessment 1992:

Arizona Department of Environmental Quality, Phoenix, Arizona, 177 p.

1992b, Ambient toxicity testing study-1991: Arizona Department of Environmental Quality, Office of Water Quality, Phoenix, Arizona.

1992c, Water quality boundaries and standards, Title 18, Chapter 11: Arizona Department of Environmental Quality, Office of Water Quality, Phoenix, Arizona, $40 \mathrm{p}$.

1992d, Human health-based guidance levels for the ingestion of contaminants in drinking water and soil: Arizona Department of Environmental Quality, Phoenix, Arizona, June 1992, v.p.

Arizona Game and Fish Department, 1982-83, An overview of lake nutrient budget methodologies: Arizona Game and Fish Department for Northern Arizona Council of Government, Flagstaff, Arizona. 1983, 1982-83 Statewide fishery investigations (F-7-R-25): Arizona Game and Fish Department, Phoenix, Arizona.

Bates, R.L., and Jackson, J.A., eds., 1980, Glossary of geology ( $2 \mathrm{~d}$ ed.): Falls Church, Virginia, American Geological Institute, 749 p.

Boner, F.C., Davis, R.G., and Duet, N.R., 1992, Water resources data for Arizona, water year 1991: U.S. Geological Survey Water-Data Report AZ-91-1, $411 \mathrm{p}$.

Busch, W.N., and Sly, P.G., 1992, The development of an aquatic habitat classification system for lakes: Boca Raton, Florida, CRC Press, 225 p.

Chow, Ven Te, 1964, Handbook of applied hydrology: New York, McGraw-Hill, Inc., v.p.
Cole, G.A., 1983, Textbook of limnology, 3d ed.: Prospect Heights, Illinois, Waveland Press, Inc., $401 \mathrm{p}$.

Corps of Engineers, 1966, Flood-damage report on flood of December 1965-January 1966, Salt and Gila Rivers, Granite Reef Dam to Gillespie Dam, Arizona: Corps of Engineers, p. 3.

Eychaner, J.H., 1987, Acidic ground-water contamination from copper mining near Globe, Arizona, in Franks, B.J., ed., Program on Toxic Water-Ground-Water Contamination, Proceedings of the Third Technical Meeting, Pensacola, Florida, March 23-27, 1987: U.S. Geological Survey Open-File Report 87-109, p. D-19-D-24.

1991, Inorganic contaminants in acidic water near Globe, Arizona, in Survival in the Desert-Water Quality and Quantity Issues into the 21st Century: Arizona Hydrological Society, Proceedings of the Third Annual Symposium, Casa Grande, Arizona, September 20-22, 1990, p. 242-252.

Faulds, J.E., 1986, Tertiary geologic history of the Salt River Canyon region, Gila County, Arizona: Tucson, University of Arizona, master's thesis, $262 \mathrm{p}$.

Frey, D.G., 1963, ed., Limnology in North America: Madison, University of Wisconsin Press, 734 p.

Gellenbeck, D.J., and Hunter, Y.R., 1994, Hydrologic data from the study of acidic contamination in the Miami Wash-Pinal Creek area, Arizona, water years 1992-93: U.S. Geological Survey Open-File Report 94-508, $103 \mathrm{p}$.

Green, C.R., and Sellers, W.D., 1964, Arizona climate: Tucson, University of Arizona Press, 503 p.

Helsel, D.R., 1990, Less than obvious: Environmental Science Technology, v. 24, no. 12, American Chemical Society, p. 1766-1774.

Helsel, D.R., and Cohn, T.A., 1988, Estimation of descriptive statistics for multiply censored water quality data: Water Resources Research, v. 24, p. 1997-2004.

Hydro Geo Chem, Inc., 1989, Investigation of acid water contamination along Miami Wash and Pinal Creek, Gila County, Arizona: Claypool, Arizona, Cyprus Miami Mining Corporation, v. 3, 140 p.

Lara, J.M., 1982, Theodore Roosevelt Lake-1981 Sedimentation Survey: Bureau of Reclamation, Denver, Colorado, $89 \mathrm{p}$.

Newell, F.H., ed., 1904, Proceedings of first conference of engineers of the Reclamation Service: U.S. Geological Survey Water-Supply and Irrigation Paper No. 93, p. 128-158.

Rinne, J.N., 1973, A limnological study of central Arizona reservoirs with reference to horizontal fish 
distribution: Tempe, Arizona State University, Ph.D. dissertation, $350 \mathrm{p}$.

Schanz, F., and Juon, J., 1983, Two different methods of evaluating nutrient limitations of periphyton bioassays, using water from the river Rhine and eight of its tributaries: Hydrobiologia, v. 102, p. 187-195.

Schumann, H.H., and Thomsen, B.W., 1972, Hydrologic regimen of lower Tonto Creek basin, Gila County, Arizona-A Reconnaissance Study: Arizona Water Commission Bulletin 3, 39 p.

Sellers, W.D., and Hill, R.H., 1974, Arizona climate: Tucson, Arizona, University of Arizona Press, $616 \mathrm{p}$.

Sellers, W.D., Hill, R.D., and Sanderson-Rae, Margaret, 1985, Arizona climate, the first hundred years: Tucson, Arizona, University of Arizona Press, $143 \mathrm{p}$.

Skibitzke, H.E., Bennett, R.R., DaCosta, J.A., Lewis, D.D., and Maddock, Thomas, Jr., 1961, Symposium on history of development of water supply in an arid area in southwestern United States-Salt River Valley, Arizona, in Groundwater in arid zones: Symposium of Athens, v. 2, International Association of Science Hydrology Publication 57, p. 706-742.

U.S. Department of the Interior, 1984, National handbook of recommended methods for water-data acquisition: U.S. Department of the Interior, Office of Water Data Coordination, Geological Survey, chaps. 3 and 5.

U.S. Environmental Protection Agency, 1974, An approach to a relative trophic index system for classifying lakes and reservoirs: Corvallis, Oregon, U.S. Environmental Protection Agency, Working Paper 24.

1977, Report on Theodore Roosevelt Lake, Gila County, Arizona: Region IX, Office of Research and Development, U.S. Environmental Protection Agency, Working Paper No. 735, 20 p.

1986, The national dioxin study, tiers 3, 5, 6, and

7: U.S. Environmental Protection Agency, Office of Water, Washington, D.C., v.p.

1992, Final rule, National primary and secondary drinking water regulations-Synthetic organic chemicals and inorganic chemicals, Title 40, Parts 141 and 143: Washington, DC., U.S. Environmental Protection Agency, Federal Register, v. 57, no. 138, July 17, 1992, p. 31,776-31,849.

U.S. Fish and Wildlife Service, 1991, Contaminants in prey of bald eagles nesting in Arizona: Phoenix, Arizona, U.S. Fish and Wildlife Service, $16 \mathrm{p}$.

Vollenweider, R.A., 1975, Input-output models with special reference to the phosphorus loading concept in limnology: Schweizerische Zeitschrift fur Hydrologie, v. 37, p. 53-84.

Wetzel, R.G., 1975, Limnology: Philadelphia, W.B. Saunders Company, 743 p. 